Uptake of alkaline earth metals in Alcyonarian spicules (Octocorallia)

Taubner I., Böhm F., Eisenhauer A., Garbe-Schönberg D., Erez J.

Preprint

Geochimica et Cosmochimica Acta

available online $2^{\text {nd }}$ February 2012

Published in Geochimica et Cosmochimica Acta, 84, 239-255 


\title{
Uptake of alkaline earth metals in Alcyonarian spicules (Octocorallia)
}

Taubner I. ${ }^{\text {a }, ~ B o ̈ h m ~ F . ~}{ }^{\text {a }}$, Eisenhauer A. ${ }^{\text {a }}$, Garbe-Schönberg D. ${ }^{b}$, Erez J. ${ }^{\mathrm{c}}$

${ }^{a}$ Helmholtz-Zentrum für Ozeanforschung Kiel - GEOMAR, Wischhofstr. 1-3, D 24148 Kiel, Germany

${ }^{\mathrm{b}}$ Institute of Geosciences, Christian-Albrechts-Universität, Kiel, Germany

${ }^{c}$ Department of Earth Sciences, The Hebrew University of Jerusalem, 91904 Jerusalem, Israel

\begin{abstract}
Alcyonarian corals (Octocorallia) living in shallow tropical seas produce spicules of high-Mg calcite with $\sim 13 \mathrm{~mole} \% \mathrm{MgCO}_{3}$. We cultured the tropical alcyonarian coral Rhythisma fulvum in experiments varying temperature $\left(19-32^{\circ} \mathrm{C}\right)$ and $\mathrm{pH}(8.15-8.44)$. Alkalinity depletion caused by spicule formation systematically varied in the temperature experiments increasing from 19 to $29^{\circ} \mathrm{C}$. Spicules were investigated for their elemental ratios $(\mathrm{Mg} / \mathrm{Ca}, \mathrm{Sr} / \mathrm{Ca})$ using ICP-OES, $\delta^{44 / 40} \mathrm{Ca}$ using TIMS, as well as $\delta^{18} \mathrm{O}$ and $\delta^{13} \mathrm{C}$ by IRMS. $\mathrm{Mg} / \mathrm{Ca}$ increased with temperature from 146 to $164 \mathrm{mmol} / \mathrm{mol}$, in good agreement with the range observed for marine inorganic calcite. $\mathrm{Mg} / \mathrm{Ca}$ increased by $1.0 \pm 0.4 \mathrm{mmol} / \mathrm{mol} /{ }^{\circ} \mathrm{C}$, similar to the sensitivity of Miliolid foraminifera. The $\mathrm{pH}$ experiments revealed a linear relationship between $\mathrm{Mg} / \mathrm{Ca}$ and carbonate ion concentration of $+0.03 \pm 0.02 \mathrm{mmol} / \mathrm{mol} / \mu \mathrm{Mol}$. Sr/Ca ranges from 2.5 to 2.9 $\mathrm{mmol} / \mathrm{mol}$ being in good agreement with other high-Mg calcites. Temperature and $\mathrm{pH}$ experiments showed linear dependencies of $\mathrm{Sr} / \mathrm{Ca}$ matching inorganic calcite trends and pointing to a decoupling of crystal precipitation rate and calcification rate. Ca isotopes range between $0.7 \%$ and $0.9 \%$ in good agreement with aragonitic scleractinian corals and calcitic coccoliths. Presumably $\mathrm{Ca}$ isotopes are fractionated by a biological mechanism that may be independent of the skeletal mineralogy. We observe no temperature trend, but a significant decrease of $\delta^{44 / 40} \mathrm{Ca}$ with increasing $\mathrm{pH}$. This inverse correlation may characterise biologically controlled intracellular calcification. Oxygen isotope ratios are higher than expected for isotopic equilibrium with a temperature sensitivity of $-0.15 \pm 0.03 \% /{ }^{\circ} \mathrm{C}$. Carbon isotope ratios
\end{abstract}


are significantly lower than expected for equilibrium and positively correlated with temperature with a slope of $0.20 \pm 0.04 \% /{ }^{\circ} \mathrm{C}$.

Many of our observations on trace element incorporation in $R$. fulvum may be explained by inorganic processes during crystal formation, which do not comply with the intracellular mode of calcification in Alcyonarian corals. The observed elemental and isotopic compositions, however, could be explained if the partitioning caused by biological mechanisms mimics the effects of inorganic processes.

\section{INTRODUCTION}

Alcyonarian spicules are a common accessory component of modern marine sediments. Their occurrences were already discussed in 19th and early 20th century publications on marine sediments. Samples collected during the H.M.S. Challenger expeditions (1873-1876) frequently showed alcyonarian spicules in shallow water deposits and occasionally in deep water "globigerina and pteropod oozes" (Thomson and Murray, 1891). Their ability to contribute significantly to some reef sediments was discussed by Cary (1917). Quantitative estimates of alcyonarian spicule frequencies in tropical, subtropical, and temperate carbonate sediments can be found in the more recent literature. Several occurrences are described from reef, lagoonal and shelf settings, where Alcyonarian spicules contribute up to 5\% of the sedimentary particles (Matthews, 1966; Stieglitz, 1972; Erez and Gill, 1977; Scoffin and Tudhope, 1985; James et al., 1999; Zuschin and Mayrhofer, 2009).

Small reef like structures are formed by spicules of the genus Sinularia, which occurs in Holocene and Pleistocene reef deposits of the western Indo-Pacific (Konishi, 1981) and in the Red Sea (Schuhmacher, 1997). Sinularia can form a rigid framework of spiculitic limestone, several meters in diameter (Kleypas, 1996).

Fossil alcyonaria spicules were reported in Pleistocene reef limestones as old as $1 \mathrm{Ma}$ from New Caledonia (Cabioch et al., 2008). The probably oldest occurrences were reported from the Silurian marls and limestones of Gotland, Sweden (Bengtson, 1981). The alcyonarian coral Rhythisma fulvum is a small polyped, flat soft coral colony, mainly found in the Red Sea and Great Barrier Reef. Like zooxanthellate corals, R. fulvum possesses photosymbionts (Alderslade, 2000). Overgrowing dead and live substrate, they form encrusting mats (2-4 mm thin). Octocorals build irregularly arranged spicules of high-Mg calcite ( 13 mole $\%$ of $\left.\mathrm{MgCO}_{3}\right)$, within vacuoles of scleroblasts confined by membranes (Kingsley and Watabe, 1985; Dunkelberger and Watabe, 1974). This makes R. fulvum a good 
model organism to study biologically controlled calcification since spicule formation is taking place in a confined space, presumably without direct contact to seawater.

Intracellular calcification is not only used by alcyonarians, but also found in some of the most important calcifiers like coccolithophorids, miliolid foraminifera and echinoderms (Weiner and Dove, 2003). A general understanding of ion processing during intracellular calcification is therefore important, and has the potential to provide clues for proxy applications and carbon cycle studies.

In order to examine induced variations in biogenic calcification a new model organism, $R$. fulvum (Fig. 1) was cultured in natural seawater under controlled laboratory conditions with variable temperature and $\mathrm{pH}$. The influence of these parameters on $\mathrm{Sr} / \mathrm{Ca}, \mathrm{Mg} / \mathrm{Ca}$ elemental ratios as well as $\mathrm{Ca}, \mathrm{C}$ and $\mathrm{O}$ isotope ratios in the $\mathrm{Mg}$-calcite spicules was investigated in this study. This is the first culture study on alcyonarian spicule composition. Available data on the chemical composition of octocorallian spicules (Chave, 1954; Ohde and Kitano, 1984; Carpenter and Lohmann, 1992; Milliman, 1974) are restricted to samples from natural marine sites.

\section{MATERIAL AND METHODS}

\subsection{Culturing Setup}

Culturing experiments were carried out in Israel at the Hebrew University of Jerusalem, Institute of Earth Sciences, in the laboratory of Prof. Jonathan Erez. The alcyonarian soft coral, Rhythisma fulvum, originated from the Gulf of Eilat and had been kept in the aquarium facilities of Prof. Jonathan Erez. Pieces of $3 \mathrm{~cm}^{2}$ were cut off the mother colony placed in a plastic petri dish for attachment and returned to the holding tank for recovery.

After five days dishes with firmly attached coral pieces were ready for experimentation. These coral pieces had restarted to grow at the edges, covering previously exposed spicules (after excising coral pieces). In order to measure the area covered by the corals basal surfaces attached to petri dishes of all coral pieces were scanned before and after the experiment. Areas were determined by using the freely available software program Image J, calibrated using graph paper. The analytical error of this procedure to determine surface areas is smaller than $0.1 \%$ ( $n=3$, standard deviation). Initial coral colony outlines were marked on the petri dishes. Initial and final scans were compared to determine newly grown edges of the corals. 
In the middle of every dish a plastic spacer was inserted to prevent the magnetic stirring bar from touching the coral during the experiment. Stirring was provided by a magnetic stirrer (Model Electronicrührer, Poly 15, Variomag ${ }^{\circledR}$ ) with a rate which was set to $350 \mathrm{rpm}$ and at which corals fully expanded their polyps. Experimental setup is described in Fig. 2.

Dishes were placed into $220 \mathrm{ml}$ clear Perspex chambers, completely filled with Red Sea seawater and closed, to prevent exchange with the atmosphere. Chambers were placed into water baths where temperature was regulated by employing a combination of a refrigerated bath circulator (Model BL-30, M.R.C. Itd., Israel), cooling water to a stable temperature of $19^{\circ} \mathrm{C}$, and single Immersion thermostat circulators (Model TEP-4, Fried Electric, Haifa, Israel) heating individual baths to higher constant temperatures (with a precision of $\pm 0.3^{\circ} \mathrm{C}$ ). Light at an irradiance of $200 \pm 8 \mu \mathrm{mol}$ photons $\mathrm{m}^{-2} \mathrm{~s}^{-1}$ was provided by metal halide lamps in a $12 \mathrm{~h} / 12 \mathrm{~h}$ light/dark cycle.

Fresh seawater of the Northern Gulf of Eilat $(S=40.7)$ was obtained from the pier at the Interuniversity Institute for Marine Sciences in Eilat (IUI), transported back to Jerusalem, and was diluted with deionised water to a salinity of 38 . Three different batches of seawater were used for experiments $\mathrm{T} 1, \mathrm{~T} 2$ and $\mathrm{pH}$, respectively. This may explain the differences in seawater carbonate chemistry between reservoirs (Table 1). The carbonate system was manipulated as described below.

The $\mathrm{pH}$ experiments were carried out at a constant temperature of $26^{\circ} \mathrm{C}$. The $\mathrm{pH}$ was measured using a $\mathrm{pH}$ probe, calibrated with a two point calibration using NBS buffers $(7.00$ and 9.22). Seawater $\mathrm{pH}$ was adjusted using 1 molar $\mathrm{HCl}$ or $\mathrm{NaOH}$ solutions. Immediately after adjusting the $\mathrm{pH}$, seawater was carefully pumped into gastight bags (Emproco LTD) in order to reduce exchange with the atmosphere. The $\mathrm{pH}$ in the seawater reservoirs were initially set to $7.60,7.90,8.20$ or 8.50 (NBS scale). During the experiments reservoir $\mathrm{pH}$ was monitored and showed very little variation (Fig. 3). The pHs in the experimental chambers were modified by the corals to average $\mathrm{pH}$ values of $8.15 \pm 0.02,8.34 \pm 0.07,8.35 \pm 0.06$ and $8.44 \pm 0.04$, respectively. The $\mathrm{pH}$ ranges represent day/night variabilities (1 standard deviation).

Experimental chambers (clear Perspex ${ }^{\circledR}$ ) holding $R$. fulvum were continuously supplied with fresh seawater from gas tight bags (reservoir) using a peristaltic pump (Model ecoline VC, Ismatec), which was set to a flow velocity of $2.9 \mathrm{~m}$ per hour. Flow rate was $220 \mathrm{ml}$ per day, which corresponds to the volume of the experimental chamber.

Seawater outflows from the experimental chambers were collected in $25 \mathrm{ml}$ conical flasks (integrated chamber water), placed in larger beakers to collect overflowing seawater and 
covered with parafilm to reduce evaporation. During $\mathrm{pH}$ experiments, reservoir $\mathrm{pH}$ was measured at the start and end and twice during the course of the experimental run. Sink $\mathrm{pH}$ was measured directly in the conical flask at the end of the 12 hour light and dark periods, respectively. The results of these measurements are shown in Fig. 3.

Total Alkalinity (TA) was determined on water samples from the reservoir and the outlet of the experimental chamber, which was collected in plastic bottles and pooled. Fluids were sampled using a plastic syringes, which were tightly closed and stored below $10^{\circ} \mathrm{C}$ in the dark for chemical analysis. TA was measured using an automatic burette (Radiometer ABU91) at the Institute of Earth Sciences, the Hebrew University of Jerusalem, Israel.

Carbonate speciation of seawater solutions was calculated using the CO2SYS programme by Lewis and Wallace (1998) and is presented in Table 1.

The experiments, all lasting between 17 and 29 days, were carried out in three runs, at 19, 22, $25,28^{\circ} \mathrm{C}(\mathrm{T} 1)$, at $23,29,32^{\circ} \mathrm{C}(\mathrm{T} 2)$, and set to different initial $\mathrm{pH}(\mathrm{pH})$, but kept at constant temperature of $26^{\circ} \mathrm{C}$. For all temperature experiments seawater $\mathrm{pH}$ of the reservoir was set to 8.2. Temperatures were monitored during the run of the experiments and varied by $\pm 0.3^{\circ} \mathrm{C}$.

\subsection{Analytical Methods}

At the end of the experiments, petri dishes with corals were scanned in a computerized scanner to determine the final surface area (and to distinguish new growth at the edges) covered by coral using the freely available software program Image J. Newly outgrown pieces of coral were carefully trimmed off, washed four times with deionised water (Milli-Q water, $18 \mathrm{M} \Omega$ ) to remove seawater and dried at $50^{\circ} \mathrm{C}$ until dry weight was stable. Organic matter was removed from spicules by keeping them in up to $10 \mathrm{ml}$ of diluted sodiumhypochlorite (NaOCl, bleach) solution (Sigma Aldrich, 1:5 dilution with Milli-Q water) for 2 hours on a rocking table. After bleaching, calcitic spicules were washed 5 times with Milli-Q water and transferred into $2 \mathrm{ml}$ pre-cleaned Eppendorf tubes. Tubes were centrifuged for 1 minute at 500 rpm, supernatant was carefully taken off and remaining spicules dried at $50^{\circ} \mathrm{C}$.

\subsubsection{Calcification Rates}

Calcification rates were determined using the well established alkalinity anomaly technique (Chisholm and Gattuso, 1991). This method uses the difference in TA between inflow (reservoir) and outflow (pooled chamber water) of the experimental chamber to calculate the 
amount of precipitated calcium carbonate $\left(\mathrm{CaCO}_{3}\right)$. Rates were normalised to initial surface area and the duration of the experiments. Additionally, we used the surface area of the newly grown coral tissue to verify calcification rates determined by the TA method.

Seven coral pieces grown in the holding tank were used to compare covered surface area with their respective total and inorganic dry weights. Area and weight showed a clear linear correlation (Fig. 4a). Bleaching of the coral tissues demonstrated that $66 \%$ of the total dry weight consists of high-Mg calcite spicules. This is in agreement with results from Konishi (1981).

At the end of the experiments the mass of high-Mg calcite spicules, determined by the surface area method and the TA method were compared. Calcification rates determined by the two methods showed no clear correlation (Fig. 4b). For three experiments the surface area method resulted in higher rates than the TA method, possibly indicating variable tissue/spicule ratios of $R$. fulvum grown under different conditions. Since tissue/spicule ratios are variable the results of the surface area method are not reliable. We therefore used calcification rates determined by the TA method.

\subsubsection{Elemental Ratios}

Elemental ratios were determined by ICP-OES using a SPECTRO CIROS ${ }^{\mathrm{CCD}}$ SOP instrument at the Institute of Geosciences, University of Kiel. For sample preparation, about 80 to $120 \mu \mathrm{g}$ of the high-Mg calcite spicules were dissolved in $2.2 \mathrm{~N}$ ultrapure $\mathrm{HCl}$, dried down and taken up in $300 \mu$ l of ultrapure $\mathrm{HNO}_{3}$. Both acids (p.A. grade, MERCK ${ }^{\circledR}$ ) were doubly distilled before use. This solution was kept in closed PFA vials on a hot plate at $110{ }^{\circ} \mathrm{C}$ overnight. Samples were evaporated to dryness and re-dissolved in a pre-calculated volume of $2 \% \mathrm{HNO}_{3}$ to give a Ca concentration of $1 \mathrm{ppm}( \pm 10 \%)$. This solution was transferred to the ICP-OES. An intensity ratio calibration procedure (deVilliers et al., 2002) was applied using a set of multi-elemental standard solutions prepared from single-element primary standards (ALFA, SPEX) and matrix-matched to $1 \mathrm{ppm} \mathrm{Ca}$. The calibration standards covered the $\mathrm{Mg} / \mathrm{Ca}$ and $\mathrm{Sr} / \mathrm{Ca}$ range of the high-Mg calcite spicules. Sample introduction comprised $70 \mathrm{~s}$ of wash-in using a PFA micro-flow-nebulizer (with a sample uptake of $200 \mu \mathrm{L} / \mathrm{min}$ ), followed by real simultaneous data acquisition during 5 individual measurements with an integration time of $20 \mathrm{~s}$ each. Analytical results represent averages from 5 replicate analyses and were calculated from background corrected intensities (i.e., raw counts per second). This procedure uses 
$\sim 0.5 \mathrm{ml}$ of sample solution. The procedural blank was below detection limit for $\mathrm{Sr}, 1 \%$ for $\mathrm{Ca}$ and 3\% for $\mathrm{Mg}$.

Long-term precision was estimated from repeat analyses of an internal "project standard" prepared from mixing equal proportions of all sample solutions. No certified standard for high-Mg calcite samples is currently available. Repeat analyses of this project standard over a period of two hours gave a precision of $\pm 0.5 \%$ and $\pm 0.7 \%$ ( $\mathrm{n}=4$, rel. standard deviation, $\mathrm{RSD}$ ) $\mathrm{mmol} / \mathrm{mol}$ for $\mathrm{Sr} / \mathrm{Ca}$ and $\mathrm{Mg} / \mathrm{Ca}$, respectively.

\subsubsection{Calcium Isotopes}

The calcium isotope ratios of high-Mg calcite spicules and seawater $\mathrm{Ca}$ were measured with a Finnigan Triton TI (Thermal Ionization Mass Spectrometer) following the method described in Heuser et al. (2002) and Heuser and Eisenhauer (2008). About 40 to $100 \mu \mathrm{g}$ of the spicules were dissolved in $2.2 \mathrm{~N}$ ultrapure $\mathrm{HCl}$, dried down and re-dissolved in $2.2 \mathrm{~N} \mathrm{HCl}$ with a $\mathrm{Ca}$ concentration of $160 \mathrm{ng} / \mu \mathrm{L}$. The sample solutions were mixed with a ${ }^{43} \mathrm{Ca} /{ }^{48} \mathrm{Ca}$ double spike, with the spike contributing about $90 \%$ of ${ }^{48} \mathrm{Ca}$.

Calcium samples of the seawater used in the culturing setup and IAPSO seawater standard were prepared in a chromatographic clean-up on cation-exchange columns (BioRad) filled with MCI Gel (75-100 $\mu \mathrm{m}$ mesh; $0.6 \mathrm{ml})$. Solutions with $4 \mu \mathrm{g}$ of Ca, spiked with a ${ }^{43} \mathrm{Ca} /{ }^{48} \mathrm{Ca}$ double spike, were loaded on the column. Elution was carried out using $1.5 \mathrm{~N} \mathrm{HCl}$. Ca blanks for the column chemistry were less than $1 \mathrm{ng}$ per sample (300 $\mathrm{ng} \mathrm{Ca}$ ). Total Ca blanks for the isotope analyses were less than $2 \%$.

About $300 \mathrm{ng}$ of the sample-spike mixtures were loaded with $\mathrm{TaCl}_{5}$ activator on an outgassed zone-refined Re filament. Measurements were made on single filaments at a temperature of about $1500^{\circ} \mathrm{C}$ and a typical ${ }^{40} \mathrm{Ca}$ signal intensity of $10 \mathrm{~V}(100 \mathrm{pA})$. Data acquisition was performed in dynamic mode. The acquired data were fractionation corrected online to the spike ${ }^{43} \mathrm{Ca} /{ }^{48} \mathrm{Ca}$ ratio of 0.748429 (Gussone 2003) using the exponential fractionation law. The double spike correction was carried out with the iterative algorithm described by Heuser et al. (2002).

The isotope values of $\mathrm{Ca}$ are reported as $\delta^{44 / 40} \mathrm{Ca}(\%)$ values relative to the NIST standard SRM915a, where $\delta^{44 / 40} \mathrm{Ca}=\left[\left({ }^{44} \mathrm{Ca} /{ }^{40} \mathrm{Ca}\right)_{\text {sample }} /\left({ }^{44} \mathrm{Ca} /{ }^{40} \mathrm{Ca}\right)_{\text {SRM915a }}-1\right] \times 1000$. The samples are normalized to the mean ${ }^{44} \mathrm{Ca} /{ }^{40} \mathrm{Ca}$ of four SRM915a analyses, run on the same turret. The sample precision is given as two times the standard error of the mean $\left(2 \mathrm{SEM}=2 \mathrm{SD} / \mathrm{n}^{0.5}\right)$ determined by repeated measurements of the sample stock solutions. The samples were 
measured at least twice. The average $2 \mathrm{SEM}$ is $0.11 \%$. The spike corrected mean ${ }^{44} \mathrm{Ca} /{ }^{40} \mathrm{Ca}$ of NIST SRM915a was 0.021187(2) (standard deviation, $\mathrm{n}=19$ ). Measurements of the IAPSO seawater salinity standard resulted in a ${ }^{44} \mathrm{Ca} /{ }^{40} \mathrm{Ca}$ of $0.021226(5)(\mathrm{n}=11)$. The corresponding $\delta^{44 / 40} \mathrm{Ca}$ of IAPSO relative to SRM915a is $1.81 \pm 0.13 \%$ ( $\left.\pm 2 \mathrm{SEM}\right)$.

The $\delta^{44 / 40} \mathrm{Ca}$ of the Red Sea seawater was determined as $1.82 \pm 0.07 \%$ ( $( \pm 2 \mathrm{SEM}, \mathrm{n}=18$ ). No significant differences in $\delta^{44 / 40} \mathrm{Ca}$ were found in seawater solutions used in the different experiments. This mean seawater value is identical within error with the IAPSO seawater standard $\delta^{44 / 40} \mathrm{Ca}\left(1.81 \pm 0.13 \%\right.$ ) and the mean seawater value $\delta^{44 / 40} \mathrm{Ca}=1.88 \pm 0.04 \%$ o reported by Hippler et al. (2003).

\subsubsection{Oxygen and Carbon Isotopes}

Oxygen and carbon isotopes of the spicules were analyzed at IFM-GEOMAR, Kiel, on a Finnigan MAT 252 equipped with a Kiel II device. Reproducibility (1SD) for $\delta^{18} \mathrm{O}$ and $\delta^{13} \mathrm{C}$ is $\pm 0.05 \%$ and $\pm 0.02 \%$, respectively. Oxygen and carbon isotope values are reported relative to V-SMOW and V-PDB, respectively, in the common $\delta$-notation.

Samples of the seawater used during the culturing were analysed for oxygen and carbon isotopic composition. Sample preparation was the same as described for DIC sampling. The $\delta^{18} \mathrm{O}$ contamination by the $\mathrm{HgCl}_{2}$ - poisoning is less than $-0.05 \%$. Chamber water for isotope analysis was available only from one experiment (T1-4), resulting in $\delta^{18} \mathrm{O}=1.61 \%$ (V-SMOW) and $\delta^{13} \mathrm{C}=-1.45 \%$ (V-PDB). These values were used to calculate oxygen and carbon isotope fractionation between fluid and spicules in all experiments.

Oxygen isotopes were analyzed on $0.5 \mathrm{ml}$ sub-samples at the Leibniz Laboratory, Kiel, applying the $\mathrm{CO}_{2}$-water isotope equilibration technique using a Finnigan gas bench II unit coupled to a Finnigan DeltaPlusXL (Bauch et al., 2005). $\mathrm{CO}_{2}$ for carbon isotope determination of DIC was extracted and measured as described by Erlenkeuser et al. (2003). The average precision for $\delta^{18} \mathrm{O}$ and $\delta^{13} \mathrm{C}$ is $\pm 0.06 \%$ (1SD) calculated from repeated sample measurements.

\section{RESULTS}

\subsection{Calcification Rate}


Results of our measurements are presented in Table 2 and shown in Fig. 5. Calcification rates for $R$. fulvum measured as the amount of $\mathrm{CaCO}_{3}$, normalized to the area of the initial coral piece $\left(\mu \mathrm{mol} / \mathrm{cm}^{2} / \mathrm{d}\right)$, show a dependence on temperature, but not on $\mathrm{pH},\left[\mathrm{HCO}_{3}{ }^{-}\right]$or $\left[\mathrm{CO}_{3}{ }^{2-}\right]$. Calcification generally increased with temperature from 19 to $29^{\circ} \mathrm{C}$. The observed rates range from 0.8 to $5.6 \mu \mathrm{mol} / \mathrm{cm}^{2} / \mathrm{d}$ (Fig. 5). From the change in total alkalinity and average spicule weight $(0.02 \mathrm{mg})$ we calculate a formation rate of about 25 spicules per day per $\mathrm{cm}^{2}$ at maximum growth rate. The reduced calcification rate found at the highest temperature $\left(32^{\circ} \mathrm{C}\right)$ was possibly caused by bleaching. The coral in this experiment was paler than the others and bleaching (loss of photosymbionts) is known to curb zooxanthellate coral calcification (Fujimura et al., 2001).

Instantaneous calcite precipitation rates - the amount of calcite precipitated per unit area of crystal surface per time - cannot be determined, because the coral calcification rates $\left(\mu \mathrm{mol} / \mathrm{cm}^{2} / \mathrm{d}\right)$ are averaged over the total duration of the experiment. Thus, higher coral calcification rates could indicate that more spicules were built per unit area of coral tissue, but the calcite precipitation rate for each spicule remained constant.

\subsection{Trace Element Ratios (Mg/Ca, $\mathrm{Sr} / \mathrm{Ca})$}

Results of elemental ratio measurements are presented in Table 2. The $\mathrm{Mg} / \mathrm{Ca}$ ratio in cultured $R$. fulvum spicules ranges from 146 to $164 \mathrm{mmol} / \mathrm{mol}\left(12.7-14.1 \mathrm{~mol} \% \mathrm{MgCO}_{3}\right)$ and shows a positive and significant correlation with temperature (Fig. 6a).

$\mathrm{Mg} / \mathrm{Ca}(\mathrm{mmol} / \mathrm{mol})=1.03 \pm 0.43 * \mathrm{~T}\left({ }^{\circ} \mathrm{C}\right)+129.6 \pm 11.1 ; \mathrm{R}^{2}=0.95 ; \mathrm{n}=5 ; \mathrm{p}=0.0047$

$\mathrm{Mg} / \mathrm{Ca}$ ratios also show a correlation with $\mathrm{pH}$. A regression of $\mathrm{Mg} / \mathrm{Ca}$ and $\mathrm{pH}$ results in a positive trend that is, however, only significant at the $90 \%$ level.

$\mathrm{Mg} / \mathrm{Ca}(\mathrm{mmol} / \mathrm{mol})=18.1 \pm 22.8 * \mathrm{pH}-1.4 \pm 189.8 ; \mathrm{R}^{2}=0.85 ; \mathrm{n}=4 ; \mathrm{p}=0.076$

A significant dependence of $\mathrm{Mg} / \mathrm{Ca}$ ratios on carbonate ion concentrations $\left(\left[\mathrm{CO}_{3}{ }^{2-}\right]\right)$ is shown by the resulting regression (Fig. 6b):

$\mathrm{Mg} / \mathrm{Ca}(\mathrm{mmol} / \mathrm{mol})=0.030 \pm 0.019 *\left[\mathrm{CO}_{3}{ }^{2-}\right]+140.5 \pm 5.6 ; \mathrm{R}^{2}=0.96 ; \mathrm{n}=4 ; \mathrm{p}=0.022$ 
$\mathrm{Sr} / \mathrm{Ca}$ in $R$. fulvum ranges from 2.5 to $2.9 \mathrm{mmol} / \mathrm{mol}$. The temperature response of $\mathrm{Sr} / \mathrm{Ca}$ in $R$. fulvum shows a weak, but significant inverse dependence (Fig. 6c):

$\mathrm{Sr} / \mathrm{Ca}(\mathrm{mmol} / \mathrm{mol})=-0.0116 \pm 0.0072 * \mathrm{~T}\left({ }^{\circ} \mathrm{C}\right)+3.13 \pm 0.18 ; \mathrm{R}^{2}=0.90 ; \mathrm{n}=5 ; \mathrm{p}=0.014$

We consider the data point of the $22^{\circ} \mathrm{C}$ experiment to be an outlier. The sample was probably contaminated with old spicules grown in the holding aquarium before the start of the experiment. Seawater of this holding tank was depleted in $\mathrm{Sr} / \mathrm{Ca}$ ratio by about $35 \%$. Twenty percent contamination by spicules grown in this seawater is sufficient to explain the measured low value.

$\mathrm{Sr} / \mathrm{Ca}$ also increases with increasing $\mathrm{pH}$ and carbonate ion concentration (Fig. 6d). However, given the limited data set $(\mathrm{n}=4)$ the effect of either parameter on $\mathrm{Sr} / \mathrm{Ca}$ in $R$. fulvum is not resolvable with statistical significance as shown in Eqs. (5) and (6).

$\mathrm{Sr} / \mathrm{Ca}(\mathrm{mmol} / \mathrm{mol})=0.69 \pm 0.75 * \mathrm{pH}-3.1 \pm 6.2 ; \mathrm{R}^{2}=0.89 ; \mathrm{n}=4 ; \mathrm{p}=0.058$

$\mathrm{Sr} / \mathrm{Ca}(\mathrm{mmol} / \mathrm{mol})=(11 \pm 12) * 10^{-4} *\left[\mathrm{CO}_{3}{ }^{2-}\right]+2.31 \pm 0.33 ; \mathrm{R}^{2}=0.89 ; \mathrm{n}=4 ; \mathrm{p}=0.056$

Two of the $\mathrm{pH}$ treatments had almost identical seawater $\mathrm{pH}$ values (8.34 and 8.35). However, we found significantly different $\mathrm{Mg} / \mathrm{Ca}$ and $\mathrm{Sr} / \mathrm{Ca}$ ratios between these treatments (t-test, $\mathrm{p}=0.0017$ and $\mathrm{p}=0.0164$, respectively). This suggests that additional factors besides $\mathrm{pH}$ are controlling $\mathrm{Mg} / \mathrm{Ca}$ and $\mathrm{Sr} / \mathrm{Ca}$ incorporation. There is no simple dependence of either $\mathrm{Mg} / \mathrm{Ca}$ or $\mathrm{Sr} / \mathrm{Ca}$ ratios on calcification rates (Fig. 7, Table 2).

\subsection{Calcium Isotope Ratios}

Calcium isotope ratios show a range in $8^{44 / 40} \mathrm{Ca}$ of $0.69 \%$ to $0.88 \%$ (Fig. 8 , Table 2). We observe no significant response to temperature of $\mathrm{Ca}$ isotope fractionation:

$\delta^{44 / 40} \mathrm{Ca}=(-5 \pm 11)^{*} 10^{-3} * \mathrm{~T}\left({ }^{\circ} \mathrm{C}\right)+0.9 \pm 0.3 ; \mathrm{R}^{2}=0.43 ; \mathrm{n}=5 ; \mathrm{p}=0.23$

However, $\delta^{44 / 40} \mathrm{Ca}$ has a weak, but significant inverse dependence on $\mathrm{pH}$ :

$\delta^{44 / 40} \mathrm{Ca}=-0.64 \pm 0.63 * \mathrm{pH}+6.1 \pm 5.3 ; \mathrm{R}^{2}=0.90 ; \mathrm{n}=4 ; \mathrm{p}=0.049$ 
Ca isotope fractionation demonstrates no significant trend with respect to $\left[\mathrm{CO}_{3}{ }^{2-}\right]\left(\mathrm{R}^{2}=0.74\right.$; $\mathrm{p}=0.14)$ and calcification rate $\left(\mathrm{R}^{2}=0.71 ; \mathrm{p}=0.16\right)$.

\subsection{Carbon and Oxygen Isotopes}

Measured oxygen isotope values show a range in $\delta^{18} \mathrm{O}$ (VSMOW) of $34.0 \%$ o to $31.6 \%$ for a temperature interval of 22 to $32^{\circ} \mathrm{C}$ (Table 3, Fig. 9a) and are significantly inversely correlated to temperature. Neglecting two outliers $\left(23\right.$ and $\left.29^{\circ} \mathrm{C}\right)$, we calculate the following regression:

$1000 \ln \left({ }^{18} \alpha\right)=-0.15 \pm 0.03 * \mathrm{~T}\left({ }^{\circ} \mathrm{C}\right)+35.0 \pm 0.9 ; \mathrm{R}^{2}=0.97 ; \mathrm{n}=6 ; \mathrm{p}=0.0003$

$\mathrm{pH}$ has no significant influence on $\delta^{18} \mathrm{O}\left(\mathrm{R}^{2}=0.39 ; \mathrm{p}=0.26\right)$. The two outliers could result from removal of organic matrix by hypochlorite bleaching.

Carbon isotope values $\left(\delta^{13} \mathrm{C}\right)$ range from $-4.2 \%$ to $-0.3 \%$ (VPDB) (Table 3, Fig. 9b) and show a positive correlation with temperature. Considering the $\delta^{13} \mathrm{C}$ of the chamber water of $1.45 \%$ the carbon isotope fractionation ranges from -2.7 to $+1.1 \%$. Neglecting the two outliers $\left(23\right.$ and $\left.29^{\circ} \mathrm{C}\right)$ deviating from the $\delta^{18} \mathrm{O}$-temperature trend, we calculate the following regression:

$1000 \ln \left({ }^{13} \alpha\right)=0.201 \pm 0.044 * \mathrm{~T}\left({ }^{\circ} \mathrm{C}\right)-7.07 \pm 1.17 ; \mathrm{R}^{2}=0.98 ; \mathrm{n}=6 ; \mathrm{p}=0.0002$

Again, there is no significant $\mathrm{pH}$ effect on the isotopic composition $\left(\mathrm{R}^{2}=0.03 ; \mathrm{p}=0.77\right)$.

Carbon and oxygen isotope fractionation are inversely correlated:

$1000 \ln \left({ }^{13} \alpha\right)=-1.49 \pm 0.44 * 1000 \ln \left({ }^{18} \alpha\right)+45.0 \pm 13.7 ; \mathrm{R}^{2}=0.83 ; \mathrm{n}=13 ; \mathrm{p}<0.0001$

\section{DISCUSSION}

\subsection{Biomineralization in Octocorallia}

Spicules in Octocorallia are built within spicule vacuoles in specialized cells, the so-called scleroblasts (Dunkelberger and Watabe, 1974). Hence calcification takes place intracellularly in a confined space with no direct contact to seawater (Dunkelberger and Watabe, 1974; 
Kingsley and Watabe, 1985; Fig. 10). This intracellular calcification mode creates special boundary conditions for the uptake of cations and their subsequent fate: (1) the cations used for calcification have to pass through at least two membranes and through the cell plasma, which may require active ion transport mechanisms. (2) As spicule formation occurs in a confined space, there is no free exchange of cations with bulk seawater. On the other hand exchange with the surrounding medium is a precondition for the expression of fractionation processes during precipitation. Consequently, intracellular calcification should result in different elemental and isotope partitioning compared to calcification in open systems. Selective ion uptake and isotope fractionation during the interaction of cations with proteins and organic matrices can be expected. Significant Rayleigh distillation effects can occur if ions in the calcifying fluid are partly used for calcification and partly returned to the seawater.

\subsection{Biogeochemistry of Intracellular Calcification}

With respect to cation processing coccolithophorids are currently the best studied example of intracellular calcification (Brownlee et al., 1995; Brownlee and Taylor, 2004; Stoll and Ziveri, 2004). Consequently, they represent a potentially informative analogue to alcyonarian spicule calcification. Element and isotope partitioning during coccolith formation should be comparable to alcyonarian spicule formation, or may at least provide a baseline for interpreting the chemical and isotopic composition of the spicules.

Coccolith $\mathrm{Sr} / \mathrm{Ca}$ and $\mathrm{Mg} / \mathrm{Ca}$ ratios, as well as calcium, oxygen and carbon isotopes have been the subject of a number of detailed studies (Stoll et al., 2002; Stoll and Ziveri, 2004; Rickaby et al., 2002; Langer et al., 2006, 2007, 2009; Gussone et al., 2006, 2007; Müller et al., 2011). Most coccolithophorids precipitate low-Mg calcite, but some species have been found to build high-Mg calcite coccoliths (Stanley et al., 2005). Coccolith $\mathrm{Mg} / \mathrm{Ca}$ ratios appear to have a similar temperature dependence as the low-Mg calcite of planktic foraminifera (Stoll et al., 2001). Oxygen isotopes show a temperature dependence very similar to inorganic calcite. However, for some species $\delta^{18} \mathrm{O}$ was found to be significantly higher than expected for isotopic equilibrium. The same species show higher than average carbon isotope values, which results in a positive correlation of carbon and oxygen isotopes (Stoll and Ziveri, 2004). Calcium isotopes in coccoliths are lighter than expected compared to inorganic calcite but show a similar temperature dependence (Gussone et al., 2006). $\mathrm{Sr} / \mathrm{Ca}$ ratios are higher than expected for inorganic calcite but display only minor temperature dependency. They have 
been shown to be strongly connected to coccolithophorid productivity (Stoll and Schrag, 2000).

None of these chemical and isotopic signatures is an unequivocal indicator of intracellular calcification and related biological processes. In fact, for some of them alternative models based on inorganic and biologic mechanisms have been proposed. For instance, to explain the strong correlation between productivity and coccolith $\mathrm{Sr} / \mathrm{Ca}$ ratios, Stoll et al. (2002) suggested a purely inorganic kinetic process. Calcification rates influence $\mathrm{Sr} / \mathrm{Ca}$ ratios by entrapping a Sr enriched layer at the crystal surface (surface entrapment sensu Watson and Liang, 1995). An alternative model based on a purely biological mechanism was proposed by Rickaby et al. (2002). They suggested a rate dependent discrimination of $\mathrm{Sr}$ in Ca channels. The Ca channels are necessary for the selective trans-membrane uptake of $\mathrm{Ca}$ into the cell and discriminate $\mathrm{Sr}^{2+}$ ions to a certain extent. Langer et al. (2006, 2009) introduced another biological model based on the limited transport capacity of ion channels in cellular membranes. They suggested that most $\mathrm{Ca}$ transported to the calcifying vesicle is immediately taken up by the growing crystal, resulting in a vesicle fluid slightly supersaturated with respect to calcite. Consequently $\left[\mathrm{Ca}^{2+}\right]$ is tightly coupled to $\left[\mathrm{CO}_{3}{ }^{2-}\right]$. In order to explain the correlation between $\mathrm{Sr} / \mathrm{Ca}$ ratios and productivity they assumed a coupling between nitrogen availability and DIC uptake, thus controlling $\left[\mathrm{CO}_{3}{ }^{2-}\right]$, which in turn leads to regulation of $\left[\mathrm{Ca}^{2+}\right]$ in the vesicle and therefore indirectly affecting the $\mathrm{Sr} / \mathrm{Ca}$ ratio in the calcifying fluid. This model has consequences for the interpretation of $\mathrm{Ca}$ isotopes in coccoliths. Because all of the Ca transported into the cells is used for calcification, there can be no isotope fractionation in the vesicle. On the other hand coccoliths are significantly enriched in light $\mathrm{Ca}$ isotopes with respect to seawater. Gussone et al. (2006) therefore suggested that the observed isotope fractionation occurs during the ion transport, most likely at the membrane ion channels, and is therefore not reflecting any of the inorganic processes of crystal precipitation.

If intracellular calcification imprints a typical chemical and isotopic pattern on skeletal elements we would expect a similar behaviour of trace elements and isotopes in coccoliths and alcyonarian spicules. Of course there are differences between coccolithophorids and alcyonarian corals that must be taken into account when comparing the skeletal composition of the two taxa. First, the mineralogy is different. Alcyonaria spicules are made of high-Mg calcite, while most coccoliths consist of low-Mg calcite with very low Mg concentrations (Stoll et al., 2001). Obviously alcyonarians do not strictly control the flux of Mg ions into the scleroblasts. In this regard they behave similar to miliolid foraminifera, which also precipitate high-Mg calcite intracellularly (Erez, 2003). The lack of selectivity against Mg may point to 
ion transport in vesicles to the site of calcification (Kingsley and Watabe, 1985). Fractionation of $\mathrm{Ca}$ isotopes may occur during transport to the calcification site as suggested by Gussone et al. (2006) and could be different for ion channel transport and vesicle transport. Second, while coccolithophores are unicellular, alcyonarian corals are multicellular organisms. Therefore the scleroblasts of alcyonarians which are located in the mesoglea are not in direct contact with seawater (Fig. 10). Ions for calcification have to be transported through the epithelia and the mesoglea, which may cause additional isotope fractionation and elemental discrimination. The $\mathrm{Sr} / \mathrm{Ca}$ ratios may show a similar behaviour in the two taxa if this ratio is controlled mainly by the ion transport and $\left[\mathrm{CO}_{3}{ }^{2-}\right]$ as suggested by Langer et al. (2006) (see previous paragraph). In the following section we will discuss the measured elemental and isotopic ratios and possible inorganic and biological mechanisms.

\subsection{Elemental ratios}

\subsection{1. $\mathrm{Mg} / \mathrm{Ca}$ Ratios}

Published element analyses on spicules of Octocorallia are mainly from Gorgoniacea with some additional data from Pennatulacea and Alcyonacea (soft corals) (Chave, 1954; Ohde and Kitano, 1984; Carpenter and Lohmann, 1992; Thresher et al., 2007). They showed Mg/Ca ratios in the range of 140 to $175 \mathrm{mmol} / \mathrm{mol}$ and 150 to $185 \mathrm{mmol} / \mathrm{mol}$ for Gorgoniacea and Alcyonacea, respectively. The measured ratios of $R$. fulvum lie in this range. From Fig. 11 it can further be seen that the observed $\mathrm{Mg} / \mathrm{Ca}$ values in $R$. fulvum are in general accord with other biotic and also abiotic high-Mg calcites. In contrast Bond et al. (2005) found much higher magnesium concentrations in the gorgonian coral Plexaurella dichotoma. However, these values were measured in the axial skeleton and not in spicules. Natural cements (Videtich, 1985) show consistently higher $\mathrm{Mg} / \mathrm{Ca}$ ratios than experimental calcites (Mucci, 1987). Rimstidt et al. (1998) explained this variability with kinetic effects during crystal growth. Consequently, the variability of biogenic high-Mg calcites does not necessarily imply a biological influence, but could also be caused by crystal growth kinetics. The $\mathrm{Mg} / \mathrm{Ca}$ ratios of $R$. fulvum and their temperature sensitivity are best compared to benthic miliolid and rotaliid foraminifera (Toyofuku et al., 2000), which show a linear temperature trend (Fig. 11). $\mathrm{Mg} / \mathrm{Ca}$ ratios of $R$. fulvum increase by $0.7 \% /{ }^{\circ} \mathrm{C}$, which is one order of magnitude lower than the $8 \pm 3 \% /{ }^{\circ} \mathrm{C}$ observed in the planktic foraminifera Globigerinoides ruber (white) (Kisakürek et al., 2008) and the $\sim 6 \% /{ }^{\circ} \mathrm{C}$ observed in coccoliths (Stoll et al., 
2001). However, it is close to the $2 \% /{ }^{\circ} \mathrm{C}$ increase in inorganic calcite (Mucci, 1987). This is in line with the high $\mathrm{Mg}$ content of the spicules that indicates a less strict biological control over cation transport in contrast to planktic foraminifera and most coccoliths (Stanley et al., 2005).

In our $\mathrm{pH}$ experiments we observed a $5.5 \pm 3.7 \mathrm{mmol} / \mathrm{mol}$ increase in the $\mathrm{Mg} / \mathrm{Ca}$ ratio while $\mathrm{pH}$ increased by roughly 0.3 units and the carbonate ion concentration doubled (Fig. 6b). The influence of seawater $\mathrm{pH}$ and carbonate chemistry on the incorporation of $\mathrm{Mg}$ into inorganic calcite has been discussed controversially in several studies:

Based on data from stoichiometric dissolution experiments Thorstenson and Plummer (1977) estimated the thermodynamic properties of high-Mg calcites (HMC). They concluded that the $\mathrm{Mg}$ content of naturally-occurring marine HMC should primarily be governed by the seawater supersaturation state (i.e. $\left[\mathrm{CO}_{3}{ }^{2-}\right]$ at constant $\left[\mathrm{Ca}^{2+}\right]$ ). However, they calculated a ten times stronger $\mathrm{Mg} / \mathrm{Ca}$ increase with rising saturation than what we observed in the alcyonarian spicules. Saturation state and precipitation rates were further discussed as possibly influencing $\mathrm{Mg}$ incorporation into calcite by Given and Wilkinson (1985).

In contradiction to these papers, several experimental studies showed that the $\mathrm{Mg} / \mathrm{Ca}$ partition coefficient in inorganic calcite is independent of the carbonate ion concentration and of precipitation rate (e.g. Mucci et al., 1985; Burton and Walter, 1991; Hartley and Mucci, 1996). Burton and Walter (1991) found no systematic change in the $\mathrm{Mg} / \mathrm{Ca}$ ratios of calcite precipitated in seawater with carbonate ion concentrations ranging from 250 to $1000 \mu \mathrm{M}$. On the other hand, they observed a positive correlation of calcite $\mathrm{Mg} / \mathrm{Ca}$ ratios with seawater $\mathrm{pH}$. However, in very similar experiments Hartley and Mucci (1996) could not reproduce this pH dependence.

In the $\mathrm{pH}$-stat experiments of Burton and Walter (1991) $\mathrm{Mg} / \mathrm{Ca}$ ratios increased linearly by about $30 \mathrm{mmol} / \mathrm{mol} / \mathrm{pH}$ unit as $\mathrm{pH}$ increased from 7 to 9 . This $\mathrm{Mg} / \mathrm{Ca}-\mathrm{pH}$ trend is compatible with the $18 \pm 12 \mathrm{mmol} / \mathrm{mol} / \mathrm{pH}$ unit increase observed in our experiments. Therefore all our observations of $\mathrm{Mg} / \mathrm{Ca}$ partitioning in $R$. fulvum can be explained in principle by inorganic mechanisms and open system behaviour. This is in clear contrast to the intracellular calcite formation of coccolithophorids, which shows a strict biological control of $\mathrm{Mg}$ incorporation. $\mathrm{Mg}$ uptake and processing probably follows different pathways in Alcyonarians and coccolithophorids.

\subsubsection{Sr/Ca Ratios}


Published $\mathrm{Sr} / \mathrm{Ca}$ ratios of Octocorallia range from 2.1 to $2.3 \mathrm{mmol} / \mathrm{mol}$ and 2.6 to 3.0 mmol/mol for Gorgoniacea and Alcyonacea, respectively (Ohde and Kitano, 1984; Carpenter and Lohmann, 1992; Thresher et al., 2007). This is in good agreement with the measured range of $R$. fulvum.

In experimental observations Tang et al. (2008a) found a possible $\mathrm{pH}$ dependence for the $\mathrm{Sr}$ incorporation into inorganic calcite, similar to $\mathrm{pH}$ controlled $\mathrm{Mg}$ incorporation in the experiments by Burton and Walter (1991). Tang et al. (2008a) suggested that $\mathrm{pH}$ controls the cation adsorption capacity at the crystal surface and therefore increasing $\mathrm{pH}$ could enhance the incorporation of foreign cations into calcite. In accordance with these observations, spicule $\mathrm{Sr} / \mathrm{Ca}$ ratios also show an increasing trend with rising $\mathrm{pH}$ in our experiments (Fig. 6d), albeit this trend is only significant at a 94\% level. The incorporation of $\mathrm{Sr}$ in inorganic calcite depends on precipitation rate (Tang et al., 2008a; Lorens 1981; Tesoriero and Pankow, 1996), which is controlled by $\left[\mathrm{CO}_{3}{ }^{2-}\right]$ (Zhong and Mucci, 1989). The observed increase in $\mathrm{Sr} / \mathrm{Ca}$ in $R$. fulvum with $\left[\mathrm{CO}_{3}{ }^{2-}\right]$ (Fig. 6d) is therefore compatible with the experiments of Tang et al. (2008a). Based on the nature of our experimental setup, it is not possible to distinguish whether $\mathrm{pH}$ or $\left[\mathrm{CO}_{3}{ }^{2-}\right]$ is the controlling factor for strontium incorporation. Nevertheless, both, $\mathrm{pH}$ and $\left[\mathrm{CO}_{3}{ }^{2-}\right]$ control on $\mathrm{Sr} / \mathrm{Ca}$ ratios, can be explained by inorganic processes (Tang et al., 2008a).

The weak temperature dependence of $\mathrm{D}_{\mathrm{Sr}}$ (strontium distribution coefficient) in R. fulvum ($0.0013 /{ }^{\circ} \mathrm{C}$ ) agrees well with experimental data of inorganic calcites (Fig. 12), precipitated at rates typical for corals, being in the order of $10^{4} \mu \mathrm{mol} / \mathrm{m}^{2} / \mathrm{h}$. $\mathrm{D}_{\mathrm{Sr}, \text { R.fulvum }}$ of about 0.3 is slightly higher than $\mathrm{D}_{\mathrm{Sr} \text {, inorg. }}(<0.2)$ measured by Tang et al. (2008a) on inorganic calcite. The slightly higher R. fulvum value can be explained by the high magnesium concentration, straining the calcite lattice, allowing easier incorporation of large Sr ions (Mucci and Morse, 1983; Ohde and Kitano, 1984; Cicero and Lohmann, 2001). The elevated Sr incorporation therefore represents a purely inorganic effect.

\subsubsection{Sr/Ca ratios, calcification rate and precipitation rate}

Various authors have shown that $\mathrm{Sr}$ partitioning in inorganically precipitated calcite is positively correlated with precipitation rate - the amount of calcium carbonate precipitated per area of crystal surface per time (e.g. Lorens, 1981; Tesoriero and Pankow, 1996; Nehrke et al., 2007; Tang et al., 2008a). However, in our experiments $\mathrm{Sr} / \mathrm{Ca}$ clearly decreases with temperature (Fig. 6c) although the corals grew faster at higher temperatures up to $27^{\circ} \mathrm{C}$ (Fig. 
5) and although higher precipitation rates can be expected with increasing temperatures. This apparent discrepancy can be reconciled by the assumption that the coral calcification rate ( $\mu \mathrm{mol}$ of $\mathrm{CaCO}_{3} / \mathrm{cm}_{\text {initial coral piece }}{ }^{2} / \mathrm{d}$ ) in the temperature experiments (Fig. 5) represents the number of spicules formed during a certain period of time. Obviously, controlled by the metabolism, at higher temperature more spicules are formed during the same period of time when compared to cooler temperatures, without changing the precipitation rate of the single spicule. The higher frequency of spicule formation does not necessarily mean that the precipitation rate has to be changed. If this model is correct the calcification rate and the spicule precipitation rate are decoupled. Following this approach it can be assumed that during higher temperatures more spicules are formed without changing the precipitation rate of the individual spicule. This would reconcile our discrepant observations from Figs. 5 and $6 \mathrm{c}$, respectively. Presumably, precipitation rates tend to vary very little as a function of different temperatures but much more as a function of the external seawater $\mathrm{pH}$ or $\left[\mathrm{CO}_{3}{ }^{2-}\right]$ as it can be seen from Fig. 6d. In these latter experiments the increase of the $\mathrm{Sr} / \mathrm{Ca}$ ratios with $\mathrm{pH}$ can be explained as a precipitation rate effect (Tang et al., 2008a). Like for $\mathrm{Mg}, \mathrm{Sr}$ incorporation in R. fulvum spicules can be explained by inorganic processes. Again, this is in contrast to coccolithophorids, where enhanced $\mathrm{Sr}$ uptake is best explained by biological controls. The investigated elements obviously show equivocal behaviour during intracellular calcification.

\subsection{Stable Isotope Ratios}

\subsubsection{Oxygen Isotopes}

The observed oxygen isotope temperature dependence of $R$. fulvum is in good agreement with the temperature slope for inorganic calcite (Kim and O'Neil, 1997). However, R. fulvum spicules show about $1 \%$ higher $\delta^{18} \mathrm{O}$ values than inorganic calcites formed at the same temperatures. It has been shown by Jiménez-López et al. (2004) and Tarutani et al. (1969) that the incorporation of magnesium in the calcite lattice changes the vibrational frequencies of the carbonate ions and thereby increases oxygen isotope fractionation. However, even considering this effect the offset of the oxygen isotope values of $R$. fulvum spicules is much larger than expected for inorganic calcite in isotopic equilibrium (Fig. 9a).

A similar offset from oxygen isotopic equilibrium was observed in some coccolithophorid species (Stoll and Ziveri, 2004). These authors suggested that a small part of the offset could 
be explained by the carbonate ion effect, i.e. the negative correlation between $\left[\mathrm{CO}_{3}{ }^{2-}\right]$ and $\delta^{18} \mathrm{O}$ first observed by Spero et al. (1997) and interpreted by Zeebe (1999). This effect would imply a low $\mathrm{pH}$ at the calcification site, which is quite unlikely, as most studies so far show high pH values in the calcifying medium (Al-Horani et al., 2003; de Noojier et al., 2009). Recent studies have suggested that experimental calcite does actually not reflect isotopic equilibrium but is depleted in ${ }^{18} \mathrm{O}$ due to kinetic effects (Dietzel et al., 2009; Day and Henderson, 2011). Coplen (2007) found calcite in equilibrium with respect to oxygen isotopes to be enriched in $\delta^{18} \mathrm{O}$ by $1.5 \%$. Therefore, the high $R$. fulvum $\delta^{18} \mathrm{O}$ values measured in calcite may well be interpreted to be in isotopic equilibrium with seawater. Alternatively, our observations may be explained by preferred incorporation of a certain amount of $\mathrm{HCO}_{3}{ }^{-}$ instead of $\mathrm{CO}_{3}{ }^{2-}$ during calcite precipitation, which may increase the $\delta^{18} \mathrm{O}$ values, because $\mathrm{HCO}_{3}{ }^{-}$is enriched in $\delta^{18} \mathrm{O}$ by about $7 \%$ (at $25^{\circ} \mathrm{C}$ ) compared to $\mathrm{CO}_{3}{ }^{2-}$ (Kim et al., 2006). However, equilibration of oxygen isotopes is a very slow process, in the order of several hours (McConnaughey, 1989), and $\mathrm{CO}_{3}{ }^{2-}$ is by far the dominant carbonate species to be incorporated into calcite forming in seawater (Kim et al., 2006). These obstacles may be overcome by additional biological mechanisms, e.g. reactions assisted by the enzyme carbonic anhydrase (Kingsley and Watabe, 1987). We therefore speculate that the heavy $\delta^{18} \mathrm{O}$ values found in R. fulvum can be explained by a biological control on the oxygen isotope equilibration time and on the carbonate precipitation mechanism (Silverman et al., 1973; McConnaughey et al., 1989).

\subsubsection{Carbon Isotopes}

Except for the two outliers at 23 and $29^{\circ} \mathrm{C}$ (samples not fitting the $\delta^{18} \mathrm{O}$-temperature trend) carbon isotopes are fractionated by -2.7 to $-0.8 \%$ (Fig. $9 \mathrm{~b}$ ). This is slightly lower than expected for inorganic precipitation (+1\%o, Romanek et al., 1992 for LMC; 1.3 $\pm 0.1 \%$, Jiménez-López et al., 2006 for HMC). The latter difference can be explained by the incorporation of isotopically light $\mathrm{CO}_{2}$ originating from respiration. The latter could cause the temperature dependence (Fig. 9b) if at higher temperatures less metabolic $\mathrm{CO}_{2}$ but more heavy seawater carbon is incorporated.

Alternatively, the temperature dependent variation of carbon isotopes might be interpreted as a kinetic fractionation effect, indicating a change in precipitation rate with temperature. Nonetheless, as already discussed under Section 4.2.2, Sr/Ca ratios indicate constant precipitation rates in all temperature experiments. Additionally, $\mathrm{Sr} / \mathrm{Ca}$ ratios in the $\mathrm{pH}$ 
experiments imply variable precipitation rates (Fig. 6d), but we observe no corresponding trend in the $\delta^{13} \mathrm{C}$ values (Table 3 ). Therefore we exclude kinetic fractionation as an explanation for the observed temperature dependence of $\delta^{13} \mathrm{C}$. This is further corroborated by the inverse correlation between oxygen and carbon isotopes (Fig. 9c), contrasting the positively correlated kinetic isotope fractionation observed in scleractinian corals and inorganic carbonates (McConnaughey, 1989; Adkins et al., 2003) as well as in the axial skeleton of gorgonians (Hill et al., 2011).

\subsubsection{Calcium Isotopes}

Calcium isotopes measured in $R$. fulvum are on average lighter than values from inorganic calcite precipitated at intermediate rates (Fig. 13a). Kısakürek et al. (2011) recently showed that in planktic foraminifera this phenomenon can be explained by the effect of high calcite precipitation rates, based on the observation of Tang et al. (2008b) that Ca isotope fractionation in inorganic calcite is strongly precipitation rate dependent.

The Ca isotope fractionation of R. fulvum agrees with that of planktic foraminifera. In addition, the inverse correlation between $\mathrm{Ca}$ isotopes and $\mathrm{Sr} / \mathrm{Ca}$ ratios (Fig. 14), previously observed in inorganic calcites (Tang et al., 2008b) further supports the inorganic controls on the element and isotope partitioning.

Similar to this inorganic mechanism explaining Ca isotope fractionation in $R$. fulvum most observations on elemental ratios and oxygen isotopes point to inorganic processes taking place in an open system where free exchange between crystal and a large volume of seawater is possible. However, this is in contradiction to the intracellular mode of calcification in alcyonarians where the calcification in a vesicle prohibits free exchange with the ambient seawater. Consequently, we have to consider which biological controls could alternatively explain the observed element and isotope partitioning.

Despite the fact that fractionation processes in planktic foraminifera and $R$. fulvum could be explained by an inorganic control - precipitation rate - it is striking that many more calcifying organisms (e.g. coccolithophorids, scleractinian corals) irrespective of their $\mathrm{CaCO}_{3}$ polymorph exhibit a $\mathrm{Ca}$ isotope fractionation intermediate between aragonite and calcite (Fig. 13a). Spicules of $R$. fulvum are made of a high $\mathrm{Mg}$-calcite, however the mean $\Delta^{44 / 40} \mathrm{Ca}(-1.05$ $\pm 0.06 \%$, 2SD) is identical within error with the mean value measured for Acropora sp. ($1.10 \pm 0.19 \%$ ), an aragonitic scleractinian coral (Fig. 13a). This latter $\Delta^{44 / 40} \mathrm{Ca}$ value has been 
interpreted by biological fractionation (Böhm et al., 2006), probably caused by transport through the coral tissue - a biological control.

A biological control of $\Delta^{44 / 40} \mathrm{Ca}$ in $R$. fulvum is further supported by the inverse correlation between $\Delta^{44 / 40} \mathrm{Ca}$ and $\left[\mathrm{CO}_{3}{ }^{2-}\right.$ ] (Fig. 13b). Gussone et al. (2007) explained a similar correlation in E. huxleyi by metabolic effects. The increased utilisation of isotopically heavy cellular $\mathrm{Ca}$ reservoirs at lower calcite supersaturation leads to heavier $\delta^{44 / 40} \mathrm{Ca}$ in the coccolith. Another metabolic effect was used by Kisakürek et al. (2011) to explain the positive $\Delta^{44 / 40} \mathrm{Ca}-\left[\mathrm{CO}_{3}{ }^{2-}\right]$ correlation of G. ruber. In this foraminifer, vacuolisation of low $\mathrm{pH}$ seawater used for calcification requires increased $\mathrm{H}^{+} / \mathrm{Ca}^{2+}$ exchange to reach the desired calcite saturation state in the vacuole. Kinetic isotope fractionation at the $\mathrm{H}^{+} / \mathrm{Ca}^{2+}$ exchanger leads to preferential uptake of light $\mathrm{Ca}$ isotopes into the vacuole. This process lowers the $\delta^{44 / 40} \mathrm{Ca}$ ratio in the vacuole at high $\mathrm{H}^{+} / \mathrm{Ca}^{2+}$ exchange rates (low external $\mathrm{pH}$, low $\left[\mathrm{CO}_{3}{ }^{2-}\right]$ ), leading to the observed positive $\Delta^{44 / 40} \mathrm{Ca}-\left[\mathrm{CO}_{3}{ }^{2-}\right]$ correlation in the foraminifera. This variable response of $\Delta^{44 / 40} \mathrm{Ca}$ to $\left[\mathrm{CO}_{3}{ }^{2-}\right]$ variations, in foraminifera on the one hand and in coccoliths and alcyonarians on the other hand (Fig. 13b), is difficult to explain with simple inorganic processes, but rather indicates biological mechanisms. If the two models described above can be confirmed, the sign of a $\Delta^{44 / 40} \mathrm{Ca}-\left[\mathrm{CO}_{3}{ }^{2-}\right]$ correlation can be used to distinguish between different calcification strategies. The inverse correlation observed in $R$. fulvum spicules could indicate the presence of a calcium reservoir that is increasingly used for calcification at lower external $\left[\mathrm{CO}_{3}{ }^{2-}\right]$.

In alcyonarians this reservoir may be represented by amorphous calcareous granules (Kingsley and Watabe, 1985). They may represent amorphous calcium carbonate (ACC). ACC is known to be significantly enriched in heavy Ca with respect to calcite or aragonite (Niedermayr et al., 2010; Gagnon et al. 2010).

\subsubsection{Correlation between Sr/Ca Ratios and Calcium Isotope Fractionation}

A biological mechanism may further be necessary to explain the positive correlation of $\mathrm{Sr} / \mathrm{Ca}$ ratios and $\left[\mathrm{CO}_{3}{ }^{2-}\right]$ in $R$. fulvum spicules (Fig. 6d). The inorganic mechanism discussed in Sections 4.2 and 4.3.2 requires a free exchange of ions between the site of calcification and a large fluid reservoir (as compared to the mass of the precipitate). However, ion exchange during spicule formation in $R$. fulvum is strictly controlled by the cell and vesicle membranes. Langer et al. $(2006,2009)$ discussed a biological mechanism for $\mathrm{Sr} / \mathrm{Ca}$ partitioning in coccolithophorids where $\left[\mathrm{Ca}^{2+}\right]$ in the calcifying vesicle is limited by the pumping capacity of 
the ion channels and hence inversely coupled to $\left[\mathrm{CO}_{3}{ }^{2-}\right]$ by the calcite supersaturation in the calcifying fluid. In contrast to $\left[\mathrm{Ca}^{2+}\right]$ the $\left[\mathrm{Sr}^{2+}\right]$ is largely independent of the latter.

Consequently $\mathrm{Sr} / \mathrm{Ca}$ ratios increase with increasing $\left[\mathrm{CO}_{3}{ }^{2-}\right]$ due to a decrease of $\left[\mathrm{Ca}^{2+}\right]$ because of increased calcite precipitation.

We suggest that a very similar mechanism controls $\mathrm{Sr} / \mathrm{Ca}$ partitioning in the calcifying vesicles of $R$. fulvum as well. In combination with the $\left[\mathrm{CO}_{3}{ }^{2-}\right]-\Delta \Delta^{44 / 40} \mathrm{Ca}$ relationship this results in the inverse correlation between $\mathrm{Sr} / \mathrm{Ca}$ ratios and $\Delta^{44 / 40} \mathrm{Ca}$ (Fig. 14). A similar correlation was observed in coccoliths by Müller et al. (2011). Hence, the correlation between $\mathrm{Sr} / \mathrm{Ca}$ ratios and $\Delta^{44 / 40} \mathrm{Ca}$ is not necessarily an indication of the inorganic, open-system mechanism described by Tang et al. (2008b) for calcite precipitation experiments. Biological mechanisms can mimic the kinetic behaviour of elemental and isotope ratios observed in these experiments and explain similar correlations in coccoliths and $R$. fulvum.

\section{CONCLUSIONS}

1) As indicated by measured elemental/isotopic proxies and long term calcification rates, calcite precipitation rate and spicule formation rate in Rhythisma fulvum are decoupled. 2) $\mathrm{Mg} / \mathrm{Ca}$ ratios in Alcyonarian spicules can potentially be used as $\left[\mathrm{CO}_{3}{ }^{2-}\right]$ and temperature proxy. Precision of $\mathrm{Mg} / \mathrm{Ca}$ measurements allows to reconstruct temperature and $\left[\mathrm{CO}_{3}{ }^{2-}\right]$ to a precision of $1{ }^{\circ} \mathrm{C}$ and $30 \mu \mathrm{mol} / \mathrm{kg}$, respectively.

3) Alcyonarian spicules show a similar $\mathrm{Ca}$ isotope fractionation as scleractinian corals irrespective of the mineralogy. This can be interpreted by biologically mediated $\mathrm{CaCO}_{3}$ precipitation obscuring the pure mineralogical effects on $\mathrm{Ca}$ isotope fractionation. The biologically induced $\mathrm{Ca}$ isotope fractionation is most likely due to the discrimination of heavy isotopes during transport through Ca selective cellular pathways (Gussone et al., 2006; Böhm et al., 2006).

4) Interpretations of the partitioning effects during cation uptake are equivocal and can be explained by biological as well as inorganic processes. Resolving this ambiguity requires a better understanding of Alcyonarian calcification and cation transport.

5) As shown by the discussion of cation uptake in intracellular calcification, biological mechanisms can mimic the effects of inorganic processes on element and isotope ratios.

\section{ACKNOWLEDGEMENTS}


Funding was provided by the German Research Council (DFG) within the Cluster of Excellence "The Future Ocean", project VARAN and by the Israel Science Foundation (ISF grant no. 870/05 to JE). Many thanks to Oz Nahum for assistance in the lab facilities of HUJI, to Ana Kolevica for guidance in Ca isotope measurements at IFM-GEOMAR and to Karin Kissling for help in element ratio measurements at the Christian-Albrecht-University in Kiel.

\section{REFERENCES}

Adkins J. F., Boyle E. A., Curry W. B. and Lutringer A. (2003) Stable isotopes in deep-sea corals and a new mechanism for "vital effects." Geochim. Cosmochim. Acta 67, 11291143

Alderslade P. (2000) Four new genera of soft corals (Coelenterata: Octocorallia), with notes on the classification of some established taxa. Zool. Med. Leiden 74, 237-249.

Al-Horani F. A., Al-Moghrabi S. M. and de Beer D. (2003) The mechanism of calcification and its relation to photosynthesis and respiration in the scleractinian coral Galaxea fascicularis. Marine Biology 142, 419-426.

Allison N., Finch A. A. and EIMF (2010) The potential origins and palaeoenvironmental implications of high temporal resolution $\delta^{18} \mathrm{O}$ heterogeneity in coral skeletons. Geochim. Cosmochim. Acta 74, 5537-5548.

Bauch D., Erlenkeuser H. and Andersen N. (2005) Water mass processes on Arctic shelves as revealed from $\delta^{18} \mathrm{O}$ of $\mathrm{H}_{2} \mathrm{O}$. Global and Planetary Change 48, 165-174.

Bengtson S. (1981) Atracosella, a Silurian Alcyonacean octocoral. J. Paleont. 55, 281-294.

Böhm F., Gussone N., Eisenhauer A., Dullo W.-C., Reynaud S. and Paytan A. (2006)

Calcium isotope fractionation in modern scleractinian corals. Geochimica et Cosmochimica Acta 70, 4452-4462.

Bond Z. A., Cohen A. L., Smith S. R. and Jenkins W. J. (2005) Growth and composition of high-Mg calcite in the skeleton of a Bermudian gorgonian (Plexaurella dichotoma):

Potential for paleothermometry, Geochem. Geophys. Geosyst. 6, Q08010, 10 pp.

Brownlee C. and Taylor A. R. (2004) Calcification in coccolithophores: A cellular perspective. In: Coccolithophores: From Molecular Processes to Global Impact (eds. H. R. Thierstein, J. R. Young) pp.31-49. 
Brownlee C., Davies M., Nimer N., Dong L. F. and Merrett M. J. (1995) Calcification, photosynthesis and intracellular regulation in Emiliania huxleyi. Bulletin de l' Institut oceanographique, Monaco no special 14, 19-35.

Burton E. A. and Walter L. M. (1991) The effects of $\mathrm{pCO}_{2}$ and temperature on magnesium incorporation in calcite in seawater and $\mathrm{MgCl}_{2}-\mathrm{CaCl}_{2}$ solutions. Geochimica et Cosmochimica Acta 55, 777-785.

Cabioch G., Montaggioni L., Thouveny N., Frank N., Sato T., Chazottes V., Dalamasso H., Payri C., Pichon M. and Semah A.-M. (2008) The chronology and structure of the western New Caledonian barrier reef tracts. Palaeogeogr. Palaeoclim. Palaeoecol. 268, 91-105.

Carpenter S. J. and Lohmann K. C. (1992) Sr/Mg ratios of modern marine calcite: Empirical indicators of ocean chemistry and precipitation rate. Geochimica et Cosmochimica Acta 56, $1837-1849$.

Cary L.R. (1917) The part played by Alcyonaria in the formation of some Pacific coral reefs. Proc. Nat. Acad. Sci. USA 3, 545-548.

Chave K. E. (1954) Aspects of the biogeochemistry of magnesium 1. Calcareous marine organisms. Journal of Geology 62, 266-283.

Chisholm, R. M. and Gattuso J.-P. (1991) Validation of the alkalinity anomaly technique for investigating calcification and photosynthesis in coral reef communities. Limnol. Oceanogr. 36, 1232-1239.

Cicero A. D. and Lohmann K. C. (2001) Sr/Mg variation during rock-water interaction: implications for secular changes in the elemental chemistry of ancient seawater. Geochimica et Cosmochimica Acta 65, 741-761.

Coplen T. B. (2007) Calibration of the calcite-water oxygen-isotope geothermometer at Devils Hole, Nevada, a natural laboratory. Geochimica et Cosmochimica Acta 71, 39483957.

Day C. C. and Henderson G.M. (2011) Oxygen isotopes in calcite grown under cave-analogue conditions. Geochimica et Cosmochimica Acta 75, 3956-3972.

de Nooijer L. J., Toyofuku T. and Kitazato H. (2009) Foraminifera promote calcification by elevating their intracellular $\mathrm{pH}$. Proceedings of the National Academy of Sciences of the United States of America 106, 15374-15378. 
de Villiers S., Greaves M. and Elderfield H. (2002) An intensity ratio calibration method for the accurate determination of $\mathrm{Mg} / \mathrm{Ca}$ and $\mathrm{Sr} / \mathrm{Ca}$ of marine carbonates by ICP-AES. Geochemistry Geophysics Geosystems 3. doi:10.1029/2001GC000169

Dietzel M., Tang J., Leis A. and Köhler S. J. (2009) Oxygen isotopic fractionation during inorganic calcite precipitation - Effects of temperature, precipitation rate and $\mathrm{pH}$. Chemical Geology 268, 107-115.

Dunkelberger D. G. and Watabe N. (1974) An ultrastructural study on spicule formation in the pennatulid colony Renilla reniformis. Tissue and Cell 6, 573-586.

Eisenhauer A., Kisakürek B. and Böhm F. (2009) Marine Calcification: An Alkali Earth Metal Isotope Perspective. Elements 5, 365-368.

Erez J. (2003) The Source of Ions for Biomineralization in Foraminifera and Their Implications for Paleoceanographic Proxies. Reviews in Mineralogy and Geochemistry 54, 115-149.

Erez J. and Gill D. (1977) Multivariate analysis of biogenic constituents in recent sediments off Ras Burka, Gulf of Elat, Red Sea. Mathematical Geology 9, 77-98.

Erlenkeuser H., Cordt H. H., Simstich J., Bauch D. and Spielhagen R. (2003) DIC stable carbon isotope pattern in surface waters of the southern Kara Sea, Sep. 2000. In Sibirian river run-off in the Kara Sea. Proceedings in Marine Science 6 (eds. R. Stein et al.). Elsevier, Amsterdam. pp. 91-110.

Friedman I. and O'Neil J. R. (1977) Compilation of Stable Isotope Fractionation Factors of Geochemical Interest. Geol. Surv. Prof. Pap. 440-KK. US Govt. Printing Office.

Fujimura H., Oomori T., Maehira T. and Miyahira K. (2001) Change of coral carbon metabolism influenced by coral bleaching. Galaxea, JCRS 3, 41-50.

Given R. K. and Wilkinson B. H. (1985) Kinetic control of morphology, composition, and mineralogy of abiotic sedimentary carbonates. Journal of Sedimentary Petrology 55, 109119.

Griffith E. M., Paytan A., Kozdon R., Eisenhauer A. and Ravelo A. C. (2008) Influences on the fractionation of calcium isotopes in planktonic foraminifera. Earth and Planetary Science Letters 268, 124-136.

Gagnon A.C., DePaolo D.J. and DeYoreo J.J. (2010) Calcium isotope signature of amorphous calcium carbonate: A probe of crystallization pathway? 2010 Fall Meeting, AGU, Abstract PP22A-08. 
Gussone N. (2003) Calcium isotopes in calcium carbonates: Calibration and application. PhD thesis, Christian-Albrechts-Universität, Kiel 134pp.

Gussone N., Eisenhauer A., Heuser A., Dietzel M., Bock B., Böhm F., Spero H. J., Lea D. W., Bijma J. and Nägler T. F. (2003) Model for kinetic effects on calcium isotope fractionation $\left(\delta^{44} \mathrm{Ca}\right)$ in inorganic aragonite and cultured planktonic foraminifera. Geochimica et Cosmochimica Acta 67, 1375-1382.

Gussone N., Böhm F., Eisenhauer A., Dietzel M., Heuser A., Teichert B. M. A., Reitner J., Wörheide G. and Dullo W.-C. (2005) Calcium isotope fractionation in calcite and aragonite. Geochimica et Cosmochimica Acta 69, 4485-4494.

Gussone N., Langer G., Thoms S., Nehrke G., Eisenhauer A., Riebesell U. and Wefer G. (2006) Cellular calcium pathways and isotope fractionation in Emiliania huxleyi. Geology 34,625 .

Gussone N., Langer G., Geisen M., Steel B. A. and Riebesell U. (2007) Calcium isotope fractionation in coccoliths of cultured Calcidiscus leptoporus, Helicosphaera carteri, Syracosphaera pulchra and Umbilicosphaera foliosa. Earth and Planetary Science Letters 260, 505-515.

Hartley G. and Mucci A. (1996) The influence of $\mathrm{pCO}_{2}$ on the partitioning of magnesium in calcite overgrowths from artificial seawater at $25^{\circ}$ and 1 atm total pressure. Geochimica et Cosmochimica Acta 60, 315-324.

Hermans J., Borremans C., Willenz P., André L. and Dubois P. (2010) Temperature, salinity and growth rate dependences of $\mathrm{Mg} / \mathrm{Ca}$ and $\mathrm{Sr} / \mathrm{Ca}$ ratios of the skeleton of the sea urchin Paracentrotus lividus (Lamarck): an experimental approach. Marine Biology 157, 12931300.

Heuser A. and Eisenhauer A. (2008) The Calcium Isotope Composition $\left(\delta^{44 / 40} \mathrm{Ca}\right)$ of NIST SRM 915b and NIST SRM 1486. Geostandards and Geoanalytical Research 32, 311-315.

Heuser A., Eisenhauer A., Gussone N., Bock B., Hansen B. T. and Nägler T. F. (2002) Measurement of calcium isotopes $\left(\delta^{44} \mathrm{Ca}\right)$ using a multicollector TIMS technique. International Journal of Mass Spectrometry 220, 385-397.

Hill T. M., Spero H. J., Guilderson T., LaVigne M., Clague D., Macalello S. and Jang N. (2011) Temperature and vital effect controls on bamboo coral (Isididae) isotope geochemistry: A test of the "lines method". Geochemistry Geophysics Geosystems 12, doi:10.1029/2010GC003443. 
Hippler D., Schmitt A.-D., Gussone N., Heuser A., Stille P., Eisenhauer A. and Nägler T. F. (2003) Ca isotopic composition of various standards and seawater, Geostandards Newsletter 27, 13-19.

James N. P., Collins L. B., Bone Y. and Hallock P. (1999) Subtropical carbonates in a temperate realm: Modern sediments on the southwest Australian Shelf. J. Sed. Res. 69, 1297-1321.

Jiménez-López C., Romanek C. S., Huertas F. J., Ohmoto H. and Caballero E. (2004) Oxygen isotope fractionation in synthetic magnesian calcite. Geochimica et Cosmochimica Acta 68, 3367-3377.

Jiménez-López C., Romanek C. S. and Caballero E. (2006) Carbon isotope fractionation in synthetic magnesian calcite. Geochimica et Cosmochimica Acta 70, 1163-1171.

Kim S.-T. and O’Neil J. R. (1997) Equilibrium and nonequilibrium oxygen isotope effects in synthetic carbonates. Geochimica et Cosmochimica Acta 61, 3461-3475.

Kim S.-T., Hillaire-Marcel C. and Mucci A. (2006) Mechanisms of equilibrium and kinetic oxygen isotope effects in synthetic aragonite at $25^{\circ} \mathrm{C}$. Geochimica et Cosmochimica Acta 70, $5790-5801$.

Kingsley R. J. and Watabe N. (1985) An autoradiographic study of calcium transport in spicule formation in the gorgonian Leptogorgia virgulata (Lamarck) (Coelenterata: Gorgonacea). Cell and Tissue Research 239, 305-310.

Kingsley R. J. and Watabe N. (1987) Role of carbonic anhydrase in calcification in the gorgonian Leptogorgia virgulata. Journal of Experimental Zoology 241, 171-180.

Kisakürek B., Eisenhauer A., Böhm F., Garbe-Schönberg D. and Erez J. (2008) Controls on shell $\mathrm{Mg} / \mathrm{Ca}$ and $\mathrm{Sr} / \mathrm{Ca}$ in cultured planktonic foraminiferan, Globigerinoides ruber (white). Earth and Planetary Science Letters 273, 260-269.

Kisakürek B., Eisenhauer A., Böhm F., Hathorne E. C. and Erez J. (2011) Controls on Calcium Isotope Fractionation in Cultured Planktic Foraminifera, Globigerinoides ruber and Globigerinella siphonifera. Geochimica et Cosmochimica Acta 75, 427-443.

Kleypas J. A. (1996) Coral reef development under naturally turbid conditions: fringing reefs near Broad Sound, Australia. Coral Reefs 15, 153-167.

Konishi K. (1981) Alcyonarian spiculite: Limestone of soft corals. Proc. 4th Int. Coral Reef Sym. 1, 643-649. 
Langer G., Gussone N., Nehrke G., Riebesell U., Eisenhauer A., Kuhnert H., Rost B., Trimborn S. and Thoms S. (2006) Coccolith strontium to calcium ratios in Emiliania huxleyi: The dependence on seawater strontium and calcium concentrations. Limnology and Oceanography 51, 310-320.

Langer G., Gussone N., Nehrke G., Riebesell U., Eisenhauer A. and Thoms S. (2007) Calcium isotope fractionation during coccolith formation in Emiliania huxleyi: Independence of growth and calcification rate. Geochemistry Geophysics Geosystems $\mathbf{8}$, doi:10.1029/2006GC001422.

Langer G., Nehrke G., Probert I., Ly J. and Ziveri P. (2009) Strain-specific responses of Emiliania huxleyi to changing seawater carbonate chemistry. Biogeosciences 6, 26372646.

Lemarchand D., Wasserburg G. and Papanastassiou D. (2004) Rate-controlled calcium isotope fractionation in synthetic calcite. Geochimica et Cosmochimica Acta 68, 46654678

Lewis E. and Wallace D. (1998) Program developed for CO2 system calculations. Carbon Dioxide Information Analysis Center, Oak Ridge National Laboratory, U.S. Department of Energy.

Lorens R. B. (1981) Sr, Cd, Mn and Co distribution coefficients in calcite as a function of calcite precipitation rate. Geochimica et Cosmochimica Acta 45, 553-561.

Matthews R. K. (1966) Genesis of recent lime mud in Southern British Honduras. J. Sed. Petr. 36, 428-454.

McConnaughey T. A. (1989) ${ }^{13} \mathrm{C}$ and ${ }^{18} \mathrm{O}$ isotopic disequilibrium in biological carbonates: II. In vitro simulation of kinetic isotope effects. Geochimica et Cosmochimica Acta 53, 163 171.

Milliman, J. D. (1974) Marine Carbonates. 375p., Springer, Berlin.

Mucci A. (1987) Influence of temperature on the composition of magnesian calcite overgrowths precipitated from seawater. Geochimica et Cosmochimica Acta 51, 19771984.

Mucci A. and Morse J. W. (1983) The incorporation of $\mathrm{Mg}^{2+}$ and $\mathrm{Sr}^{2+}$ into calcite overgrowths: influences of growth rate and solution composition. Geochimica et Cosmochimica Acta 47, 217-233. 
Mucci A., Morse J. W. and Kaminsky M. S. (1985) Auger spectroscopy analysis of magnesian calcite overgrowths precipitated from seawater and solutions of similar composition. American Journal of Science 285, 289-305.

Müller M. N., Kısakürek B., Buhl D., Gutperlet R., Kolevica A., Riebesell U., Stoll H. and Eisenhauer A. (2011) Response of the coccolithophores Emiliania huxleyi and Coccolithus braarudii to changing seawater $\mathrm{Mg}^{2+}$ and $\mathrm{Ca}^{2+}$ concentrations: $\mathrm{Mg} / \mathrm{Ca}, \mathrm{Sr} / \mathrm{Ca}$ ratios and $\delta^{44 / 40} \mathrm{Ca}, \delta^{26 / 24} \mathrm{Mg}$ of coccolith calcite. Geochimica et Cosmochimica Acta 75, 2088-2102.

Nehrke G., Reichart G.J., Van Cappellen P., Meile C. and Bijma J. (2007) Dependence of calcite growth rate and Sr partitioning on solution stoichiometry: Non-Kossel crystal growth. Geochimica et Cosmochimica Acta 71, 2240-2249.

Niedermayr A., Dietzel M., Kisakürek B., Böhm F., Köhler S. J., Leis A. and Eisenhauer A. (2010) Calcium Isotopic Fractionation during Precipitation of Calcium Carbonate Polymorphs and ACC at Low Temperatures. Geophysical Research Abstracts 12, EGU2010-12448-2.

Ohde S. and Kitano Y. (1984) Coprecipitation of strontium with marine Ca-Mg carbonates. Geochemical Journal 18, 143-146.

Rickaby R. E. M., Schrag D. P., Zondervan I. and Riebesell U. (2002) Growth rate dependence of Sr incorporation during calcification of Emiliania huxleyi. Global Biogeochemical Cycles 16, doi:10.1029/2001GB001408.

Rimstidt J. D., Balog A. and Webb J. (1998) Distribution of trace elements between carbonate minerals and aqueous solutions. Geochimica et Cosmochimica Acta 62, 1851-1863.

Romanek C. S., Grossman E. L. and Morse J. W. (1992) Carbon isotopic fractionation in synthetic aragonite and calcite: Effects of temperature and precipitation rate. Geochimica et Cosmochimica Acta 56, 419-430.

Schuhmacher H. (1997) Soft corals as reef builders. Proc. 8th Int. Coral Reef Sym. 1, 499502.

Scoffin T. P. and Tudhope A.W. (1985) Sedimentary environments of the Central Region of the Great Barrier Reef of Australia. Coral Reefs 4, 81-93.

Silverman D.N. (1973) Carbonic anhydrase catalyzed oxygen-18 exchange between bicarbonate and water. Archives of Biochemistry and Biophysics, 155, 452-457.

Spero H. J., Bijma J., Lea D. W. and Bemis B. E. (1997) Effect of seawater carbonate concentration on foraminiferal carbon and oxygen isotopes. Nature 390, 497-500. 
Stanley S. M., Ries J. B. and Hardie L. A. (2005) Seawater chemistry, coccolithophore population growth, and the origin of Cretaceous chalk. Geology 33, 593-596.

Stieglitz R. D. (1972) Scanning electron microscopy of the fine fraction of recent carbonate sediments from Bimini, Bahamas. J. Sed. Petr. 42, 211-226.

Stoll H. M. and Schrag D. P. (2000) Coccolith $\mathrm{Sr} / \mathrm{Ca}$ as a new indicator of coccolithophorid calcification and growth rate. Geochemistry Geophysics Geosystems 1, doi:10.1029/1999GC000015.

Stoll H. M. and Ziveri P. (2004) Coccolithophorid-based geochemical paleoproxies. In Coccolithophores: From Molecular Processes to Global Impact (eds. H. R. Thierstein, Y. R. Young). pp. 529-562.

Stoll H. M., Encinar J. R., Garcia Alonso J. I., Rosenthal Y., Probert I. and Klaas C. (2001) A first look at paleotemperature prospects from $\mathrm{Mg}$ in coccolith carbonate: Cleaning techniques and culture measurements. Geochemistry Geophysics Geosystems 2 , doi:10.1029/2000GC000144.

Stoll H. M., Rosenthal Y. and Falkowski P. G. (2002) Climate proxies from Sr/Ca of coccolith calcite: calibrations from continuous culture of Emiliania huxleyi. Geochimica et Cosmochimica Acta 66, 927-936.

Tang J., Köhler S. J. and Dietzel M. (2008a) $\mathrm{Sr}^{2+} / \mathrm{Ca}^{2+}$ and ${ }^{44} \mathrm{Ca} /{ }^{40} \mathrm{Ca}$ fractionation during inorganic calcite formation: I. Sr incorporation. Geochimica et Cosmochimica Acta 72, 3718-3732.

Tang J., Dietzel M., Böhm F., Köhler S. J. and Eisenhauer A. (2008b) $\mathrm{Sr}^{2+} / \mathrm{Ca}^{2+}$ and ${ }^{44} \mathrm{Ca} /{ }^{40} \mathrm{Ca}$ fractionation during inorganic calcite formation: II. Ca isotopes. Geochimica et Cosmochimica Acta 72, 3733-3745.

Tarutani T., Clayton R. N. and Mayeda T. K. (1969) The effect of polymorphism and magnesium substitution on oxygen isotope fractionation between calcium carbonate and water. Geochimica et Cosmochimica Acta 33, 987-996.

Tesoriero A. J. and Pankow J. F. (1996) Solid solution partitioning of $\mathrm{Sr}^{2+}, \mathrm{Ba}^{2+}$, and $\mathrm{Cd}^{2+}$ to calcite. Geochimica et Cosmochimica Acta 60, 1053-1063.

Thomson C. W. and Murray J. (1891) "Report on the scientific results of the voyage of H.M.S. Challenger during the years 1873-76. Deep-sea deposits" Scripps Institution of Oceanography Library. Report on the scientific results of the voyage of H.M.S. Challenger during the years 1873-76: Paper 6. 
Thorstenson D. C. and Plummer L. N. (1977) Equilibrium criteria for two-component solids reacting with fixed composition in an aqueous phase - example: the magnesian calcites. American Journal of Science 277, 1203-1223.

Thresher R. E., MacRae C. M., Wilson N. C. and Gurney R. (2007) Environmental effects on the skeletal composition of deep-water gorgonians (Keratoisis spp.; Isididae). Bulletin of Marine Science 81, 409-422.

Toyofuku T., Kitazato H., Kawahata H., Tsuchiya M. and Nohara M. (2000) Evaluation of $\mathrm{Mg} / \mathrm{Ca}$ thermometry in foraminifera: Comparison of experimental results and measurements in nature. Paleoceanography 15, 456-464.

Videtich P. E. (1985) Electron microprobe study of Mg distribution in Recent Mg calcites and recrystallized equivalents from the Pleistocene and Tertiary. Journal of Sedimentary Petrology 55, 421-429.

Watson E. B. and Liang Y. 1995. A simple model for sector zoning in slowly grown crystals: Implications for growth rate and lattice diffusion, with emphasis on accessory minerals in crustal rocks. American Mineralogist 80, 1179-1187.

Weiner S. and Dove P. M. (2003) An overview of biomineralization processes and the problem of the vital effect. Rev. Min. Geochem. 54, 1-29.

Zeebe R. E. (1999) An explanation of the effect of seawater carbonate concentration on foraminiferal oxygen isotopes. Geochimica et Cosmochimica Acta 63, 2001-2007.

Zhong S. and Mucci A. (1989) Calcite and aragonite precipitation from seawater solutions of various salinities: Precipitation rates and overgrowth compositions. Chemical Geology 78, 283-299.

Zuschin M. and Mayrhofer S. (2009) Brachiopods from cryptic coral reef habitats in the northern Red Sea. Facies 55, 335-344. 


\section{Figure captions}

Fig. 1: Micro-photographs of Rhythisma fulvum colony. a) Circular polyps with retracted tentacles. White objects in connecting tissue are high-Mg calcite spicules. b) Detail from lower left of (a). Inset shows polyp with extended tentacles. Spicules extending from the tissue are visible in the circled area. c) Isolated spicules consisting of high-Mg calcite.

Fig. 2: Experimental setup used in temperature and $\mathrm{pH}$ experiments for culturing R. fulvum. Inset on the left shows top view of the chamber with coral piece on the left and magnetic stirring bar on the right.

Fig. 3: Seawater $\mathrm{pH}$ in the Reservoir and representative example of day/night $\mathrm{pH}$ in experimental Chamber for the four $\mathrm{pH}$ experiments (a-d). Reservoir $\mathrm{pHs}$ were measured four times during the experiments, but are plotted separately for clarity. No measurements were taken between the 8th and 10th of March.

Fig. 4: Covered surface area of $R$. fulvum in correlation with its respective dry weight. a) total dry weight is indicated by filled symbols, whereas empty symbols represent data for inorganic dry weight. b) Correlation between newly built spicules calculated by change in covered area and change in total alkalinity. Bold line indicates a 1:1 ratio between the two methods. Error bars indicate $\pm \operatorname{SEM}(n=3)$. Error bars on 'changes in surface area' are smaller than symbols.

Fig. 5: Growth rates of $R$. fulvum in response to temperature calculated from change in total alkalinity and normalised to initial covered area, which is a proxy of coral biomass. Error bars on temperature and growth rates denote maximum range of changes in water baths and \pm SEM, respectively.

Fig. 6: Elemental ratios of $R$. fulvum spicules. a) $\mathrm{Mg} / \mathrm{Ca}$ ratios plotted against temperature and (b) calculated carbonate ion concentration from $\mathrm{pH}$ experiments; c) $\mathrm{Sr} / \mathrm{Ca}$ ratios plotted against temperature and (d) calculated carbonate ion concentration from $\mathrm{pH}$ experiments. Element ratio error bars represent \pm 2 SD from repeated measurements $(n=4)$ of project standard (section 2.2.2). Error bars on temperature denote maximum range of changes in water baths. Error bars on $\left[\mathrm{CO}_{3}{ }^{2-}\right]$ show the maximum range calculated from $\mathrm{pH}$ day/night fluctuations and precision of TA measurements. Outlier in lower left panel was not included in regression calculation. Sampling material was probably contaminated with old sample 
grown before experiment (see text). Labels close to symbols indicate corresponding $\mathrm{pH}$ values of seawater.

Fig. 7: $\mathrm{Mg} / \mathrm{Ca}$ ratios plotted against calcification rates in $R$. fulvum. Error bars on $\mathrm{Mg} / \mathrm{Ca}$ represent $\pm 2 \mathrm{SD}$ from repeated measurements $(\mathrm{n}=4)$ of project standard. Error bars on calcification rates denote \pm SEM.

Fig. 8: Calcium isotope ratios of R. fulvum spicules plotted against (a) temperature and (b) $\mathrm{pH}$. Error bars on $\mathrm{Ca}$ isotopes represent $\pm 2 \mathrm{SEM}$. Error bars on temperature and $\mathrm{pH}$ denote maximum range of changes in water baths and day/night fluctuations of $\mathrm{pH}$ in the chambers (1SD), respectively. Numbers next to symbols represent corresponding $\left[\mathrm{CO}_{3}{ }^{2-}\right]$ in seawater.

Fig. 9: Temperature dependence of (a) oxygen $\left(\delta^{18} \mathrm{O}\right)$ and (b) carbon $\left(\delta^{13} \mathrm{C}\right)$ isotopes in $R$. fulvum spicules. c) cross-plot of carbon and oxygen isotopes shows a negative correlation. Filled and empty symbols are data from temperature and $\mathrm{pH}$ experiments, respectively. Grey symbols are outliers. Dashed lines represent isotope equilibria of high-Mg calcites with 13 mole-\% $\mathrm{MgCO}_{3}$ for (a) oxygen isotopes (Kim and O’Neil, 1997; Jiménez-López et al., 2004) and (b) carbon isotopes (Jiménez-López et al., 2006).

Fig. 10: Schematic model of spicule location in Octocorallia. OE outer epithelium; M mesoglea; Sc scleroblasts; SV spicule vacuole; S spicule

Fig. 11: Temperature dependencies of $\mathrm{Mg} / \mathrm{Ca}$ ratios in different high- $\mathrm{Mg}$ calcites. Experimental inorganic calcite (dashed line) from Mucci (1987); inorganic high-Mg calcite (dotted line) from Rimstidt et al. (1998); cultured, juvenile echinoids, Paracentrotus lividus from Hermans et al. (2010); benthic foraminifera, Planoglabratella opercularis from Toyofuku et al. (2000); natural Mg calcite cements (dash-dot line) from Videtich (1985) compared to Alcyonarian coral spicules of R. fulvum.

Fig. 12: Temperature dependence of strontium distribution coefficient $\left(\mathrm{D}_{\mathrm{Sr}}\right)$ of $R$. fulvum, calculated with $\mathrm{Sr} / \mathrm{Ca}=8.8 \mathrm{mmol} / \mathrm{mol}$ for Red Sea seawater (Kisakürek et al., 2008) and corrected for the effect of $\mathrm{Mg}$ on $\mathrm{Sr}$ incorporation (Mucci and Morse, 1983). Bold black and grey lines show temperature dependence of experimental inorganic calcite for two different 
crystal growth rates $\left(\mathrm{R}, 10^{2.6}\right.$ and $10^{4} \mu \mathrm{mol} / \mathrm{m}^{2} / \mathrm{h}$ ) from Tang et al. (2008a). Errors on $\mathrm{D}_{\mathrm{Sr}}$ and temperature are smaller than symbols.

Fig. 13: Calcium isotope fractionation $\left(\Delta^{44 / 40} \mathrm{Ca}\right)$ in high-Mg calcite spicules of $R$. fulvum. a) temperature experiments compared to published inorganic and biogenic carbonates. $R$. fulvum plots in the range of aragonitic scleractinian coral (Acropora sp.; Böhm et al., 2006) and planktic foraminifera (Griffith et al., 2008, core top samples). Inorganic calcites from Tang et al. (2008b, regression through data from experiments with precipitation rates $\log (\mathrm{R})=2.8$ to 3.6, in $\left.\mu \mathrm{mol} / \mathrm{m}^{2} / \mathrm{h}\right)$. Inorganic aragonites from Gussone et al. $(2003,2005)$. b) $\mathrm{pH}$ experiments: $R$. fulvum data plotted against $\left[\mathrm{CO}_{3}{ }^{2-}\right]$ calculated from $\mathrm{pH}$ and TA lie in the same range as $E$. huxleyi (Gussone et al., 2006) and G. ruber (Kisakürek et al., 2011). Inorganic calcites of Lemarchand et al. (2004) show a steep positive slope, in contrast to inorganic calcites from Tang et al. (2008b), which showed a steep negative slope (see also Eisenhauer et al., 2009). The latter plot outside of the displayed $\left[\mathrm{CO}_{3}{ }^{2-}\right]$ range and are not shown in the figure. Data are not shown. $\Delta^{44 / 40} \mathrm{Ca}$ of $R$. fulvum was calculated with a $\delta^{44 / 40} \mathrm{Ca}_{\text {seawater }}$ of $1.82 \%$. Error bars on $\left[\mathrm{CO}_{3}{ }^{2-}\right]$ show the maximum range calculated from $\mathrm{pH}$ day/night fluctuations and precision of TA measurements.

Fig. 14: Calcium isotope fractionation of $R$. fulvum plotted against $\mathrm{D}_{\mathrm{Sr}}$ and compared to coccolith data from Müller et al. (2011). Numbers next to symbol indicate pH (upper) and corresponding $\left[\mathrm{CO}_{3}{ }^{2-}\right]$ in seawater (lower, $\mu \mathrm{mol} / \mathrm{kg}$ ). 


\section{Tables}

Table 1

Carbonate speciation in seawater solutions.

Reservoir

\begin{tabular}{|c|c|c|c|c|c|c|c|c|c|}
\hline & $\begin{array}{c}\mathrm{pH} \\
\text { (NBS) }\end{array}$ & DIC & $\begin{array}{r}\mathrm{HCO}_{3}^{-} \\
(\mu \mathrm{m}\end{array}$ & $\begin{array}{l}\mathrm{CO}_{3}{ }^{2-} \\
\left.\mathrm{kg}^{-1}\right)\end{array}$ & $\mathrm{CO}_{2}{ }^{*}$ & $\begin{array}{c}\mathrm{pCO}_{2} \\
\text { (ppmv) }\end{array}$ & $\begin{array}{c}\text { TA } \\
\left(\mu \mathrm{eq} \mathrm{kg}{ }^{-1}\right)\end{array}$ & SEM & $\Omega_{\mathrm{arg}}$ \\
\hline$(1-4)$ & 8.201 & 1923 & 1661 & 252 & 9.9 & 364.6 & 2280 & 1.0 & 3.93 \\
\hline$(5-7)$ & 8.200 & 1902 & 1643 & 249 & 9.8 & 360.6 & 2257 & 2.3 & 3.89 \\
\hline $\mathrm{pH}$ & 8.528 & 1739 & 1312 & 424 & 3.7 & 135.3 & 2357 & 0.5 & 6.61 \\
\hline$b$ & 8.206 & 1793 & 1546 & 238 & 9.1 & 334.7 & 2138 & 1.0 & 3.71 \\
\hline c & 7.918 & 1809 & 1658 & 132 & 18.9 & 696.8 & 1989 & 1.7 & 2.05 \\
\hline d & $\begin{array}{r}7.666 \\
\pm 0.002\end{array}$ & $\begin{array}{l}1820 \\
\text { SEM) }\end{array}$ & 1709 & 76 & 34.9 & 1283 & 1901 & 2.9 & 1.18 \\
\hline
\end{tabular}

\section{Chamber}

\begin{tabular}{|c|c|c|c|c|c|c|c|c|c|c|c|c|}
\hline & & $\begin{array}{c}\mathrm{T} \\
\left({ }^{\circ} \mathrm{C}\right)\end{array}$ & $\begin{array}{c}\text { pH } \\
\text { (NBS) }\end{array}$ & $1 S D$ & DIC & $\begin{array}{r}\mathrm{HCO}_{3}{ }^{-} \\
(\mu \mathrm{mol}\end{array}$ & $\begin{array}{l}\mathrm{CO}_{3}{ }^{2-} \\
\left.\mathrm{gg}^{-1}\right)\end{array}$ & $\mathrm{CO}_{2}{ }^{*}$ & $\begin{array}{c}\mathrm{pCO}_{2} \\
\text { (ppmv) }\end{array}$ & $\begin{array}{c}\text { TA } \\
\left(\mu e q \text { kg }^{-1}\right)\end{array}$ & SEM & $\Omega_{\text {arg }}$ \\
\hline \multirow[t]{4}{*}{ T1 } & 1 & 19 & & & & & & & & 2171 & 0.9 & \\
\hline & 2 & 22 & & & & & & & & 2173 & 1.9 & \\
\hline & 3 & 25 & & & & & & & & 2103 & 1.5 & \\
\hline & 4 & 28 & & & & & & & & 2024 & 2.8 & \\
\hline \multirow[t]{3}{*}{ T2 } & 5 & 23 & 8.256 & 0.039 & 1865 & 1605 & 251 & 8.8 & 300.8 & 2226 & 0.5 & \\
\hline & 6 & 29 & 8.314 & 0.023 & 1751 & 1433 & 312 & 6.3 & 248.5 & 2205 & 3.4 & \\
\hline & 7 & 32 & 8.246 & 0.018 & 1809 & 1496 & 306 & 7.4 & 311.0 & 2250 & 2.4 & \\
\hline \multirow[t]{4}{*}{ pH } & $a$ & 26 & 8.442 & 0.038 & 1792 & 1414 & 373 & 4.8 & 178.4 & 2333 & 1.1 & 5.8 \\
\hline & b & 26 & 8.345 & 0.058 & 1675 & 1374 & 295 & 5.8 & 213.3 & 2113 & 0.6 & 4.5 \\
\hline & c & 26 & 8.335 & 0.065 & 1564 & 1293 & 265 & 5.8 & 210.3 & 1968 & 0.4 & \\
\hline & $d$ & 26 & 8.153 & 0.018 & 1587 & 1390 & 188 & 9.2 & 342.1 & 1872 & 1.0 & \\
\hline
\end{tabular}

Carbonate speciation was calculated from measured TA and $\mathrm{pH}$ using the freely available CO2SYS program by Lewis and Wallace (1998). Reservoir: Seawater carbonate chemistry before entering the experimental chamber (see Fig. 2). Standard error of the mean (SEM) for TA and $\mathrm{pH}$ was calculated from three repeat measurements on the same sample. Chamber: seawater was collected from the outflow of the experimental chamber and TA was determined. $\mathrm{pH}$ represents the calculated average of 4 day and night $\mathrm{pH}$ pairs randomly chosen over the course of the experiment. 1SD denotes day/night fluctuations of $\mathrm{pH}$ in the chamber. Experiments were carried out in three runs: T1 represents first temperature set at $\mathrm{T}=19,22,25$ and $28^{\circ} \mathrm{C}(1-4), \mathrm{T} 2$ was performed at 23,29 and $32^{\circ} \mathrm{C}(5-7)$, while $\mathrm{pH}$ experiments were all carried out at a constant temperature of $26^{\circ} \mathrm{C}$. The $\mathrm{pH}$ of the temperature experiments was only monitored for $\mathrm{T} 2$. 
Table 2

Elemental and $\mathrm{Ca}$ isotope ratios of $R$. fulvum.

\begin{tabular}{ccccccccc} 
& & $\begin{array}{c}\mathrm{T} \\
\mathrm{pH}\end{array}$ & $\begin{array}{c}\left.\mathrm{CO}_{3}{ }^{2}\right] \\
(\mu \mathrm{Mg} / \mathrm{Ca}\end{array}$ & $\begin{array}{c}\mathrm{Sr} / \mathrm{Ca} \\
(\mathrm{mmol} / \mathrm{mol})\end{array}$ & $\begin{array}{c}\delta^{44 / 40} \mathrm{Ca} \\
(\% \circ)\end{array}$ & $\begin{array}{c}\text { calcification rate } \\
\left(\mu \mathrm{mol} \mathrm{CaCO} \mathrm{Cm}_{\text {initial coral piece }}{ }^{-2} \mathrm{~d}^{-1}\right)\end{array}$ \\
\hline $\mathrm{T} 1$ & 1 & 19 & & & 149.8 & 2.93 & & $2.26 \pm 0.028$ \\
& 2 & 22 & & & 152.3 & 2.66 & $0.81 \pm 0.20$ & $2.42 \pm 0.049$ \\
& 3 & 25 & & & 156.3 & 2.84 & $0.75 \pm 0.07$ & $5.16 \pm 0.053$ \\
& 4 & 28 & & & 156.9 & 2.82 & $0.74 \pm 0.22$ & $3.78 \pm 0.044$ \\
$\mathrm{~T} 2$ & 5 & 23 & 8.256 & 250.8 & 152.4 & 2.83 & $0.81 \pm 0.10$ & $3.54 \pm 0.272$ \\
& 6 & 29 & 8.314 & 311.5 & & & $0.76 \pm 0.13$ & $5.58 \pm 0.448$ \\
& 7 & 32 & 8.246 & 305.8 & 163.5 & 2.76 & $0.75 \pm 0.05$ & $0.75 \pm 0.342$ \\
$\mathrm{pH}$ & $\mathrm{a}$ & 26 & 8.442 & 373.1 & 155.2 & 2.66 & $0.69 \pm 0.07$ & $2.69 \pm 0.115$ \\
& $\mathrm{~b}$ & 26 & 8.345 & 294.8 & 153.4 & 2.64 & $0.77 \pm 0.06$ & $2.83 \pm 0.158$ \\
& $\mathrm{c}$ & 26 & 8.335 & 264.9 & 151.4 & 2.56 & $0.72 \pm 0.11$ & $2.44 \pm 0.173$ \\
& d & 26 & 8.153 & 188.2 & 149.7 & 2.46 & $0.88 \pm 0.11$ & $3.03 \pm 0.383$
\end{tabular}

$\mathrm{pH}$ and $\left[\mathrm{CO}_{3}{ }^{2-}\right]$ were taken from Table 1. Results for $\mathrm{Mg} / \mathrm{Ca}, \mathrm{Sr} / \mathrm{Ca}$ and $\delta^{44 / 40} \mathrm{Ca}$ represent mean $\pm 2 \mathrm{SEM}$. The errors on $\mathrm{Sr} / \mathrm{Ca}$ and $\mathrm{Mg} / \mathrm{Ca}$ with $\pm 0.5 \%$ and $\pm 0.7 \%(\mathrm{n}=4$, rel. standard deviation, RSD), respectively, were calculated from repeats of an internal project standard (see section 2.2.2). Errors on calcification rates $( \pm$ SEM) were calculated from triplicate $\Delta T A$ and surface area measurements. 
Table 3

Stable oxygen and carbon isotopes of $R$. fulvum.

\begin{tabular}{|c|c|c|c|c|c|c|c|c|}
\hline & & $\begin{array}{c}\mathrm{T} \\
\left({ }^{\circ} \mathrm{C}\right)\end{array}$ & $\begin{array}{c}\mathrm{pH} \\
\text { (NBS) }\end{array}$ & $\begin{array}{l}\delta^{18} \mathrm{O}_{\mathrm{CaCO}} \\
(\% \circ \mathrm{VPDB})\end{array}$ & $\begin{array}{c}\delta^{18} \mathrm{O}_{\mathrm{CaCO}} \\
(\% \circ \mathrm{VSMOW})\end{array}$ & $10^{3} \ln \left({ }^{18} \alpha\right)$ & $\begin{array}{l}\delta^{13} \mathrm{C}_{\mathrm{CaCO}} \\
(\% \circ \text { VPDB })\end{array}$ & $10^{3} \ln \left({ }^{13} \alpha\right)$ \\
\hline \multirow[t]{5}{*}{ T1 } & $2 a$ & 22 & & 3.07 & 34.02 & 31.85 & -4.18 & -2.74 \\
\hline & $2 b$ & 22 & & 3.10 & 34.06 & 31.88 & -4.17 & -2.73 \\
\hline & 3 & 25 & & 2.48 & 33.41 & 31.26 & -3.35 & -1.91 \\
\hline & $4 a$ & 28 & & 2.04 & 32.96 & 30.82 & -2.81 & -1.36 \\
\hline & $4 b$ & 28 & & 2.12 & 33.05 & 30.91 & -2.78 & -1.33 \\
\hline \multirow[t]{3}{*}{ T2 } & 5 & 23 & & 1.82 & 32.74 & 30.60 & -1.53 & -0.08 \\
\hline & 6 & 29 & & 0.75 & 31.64 & 29.54 & -0.32 & 1.13 \\
\hline & 7 & 32 & & 1.69 & 32.60 & 30.47 & -2.24 & -0.80 \\
\hline \multirow[t]{5}{*}{$\mathrm{pH}$} & $a_{1}$ & & 8.442 & 2.30 & 33.23 & 31.08 & -2.94 & -1.50 \\
\hline & $a_{2}$ & & 8.442 & 2.28 & 33.21 & 31.06 & -2.30 & -0.86 \\
\hline & $b$ & & 8.345 & 2.93 & 33.88 & 31.71 & -3.79 & -2.35 \\
\hline & c & & 8.335 & 2.74 & 33.68 & 31.52 & -2.50 & -1.06 \\
\hline & $d$ & & 8.153 & 2.72 & 33.67 & 31.50 & -2.90 & -1.45 \\
\hline
\end{tabular}

$\delta^{18} \mathrm{O}$ and $\delta^{13} \mathrm{C}$ of culturing seawater was $1.61 \%$ and $-1.45 \%$, respectively. VPDB to VSMOW conversion was calculated according to Friedman and O’Neil (1977). 

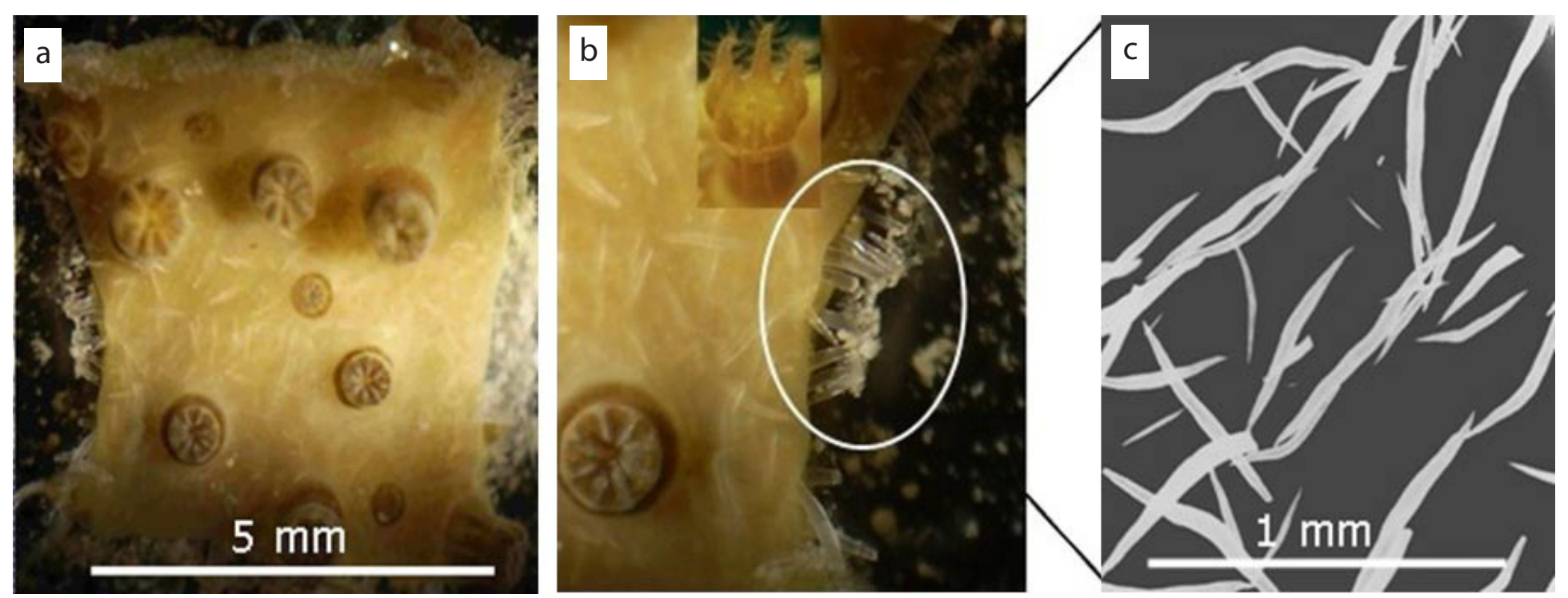

Figure 1 


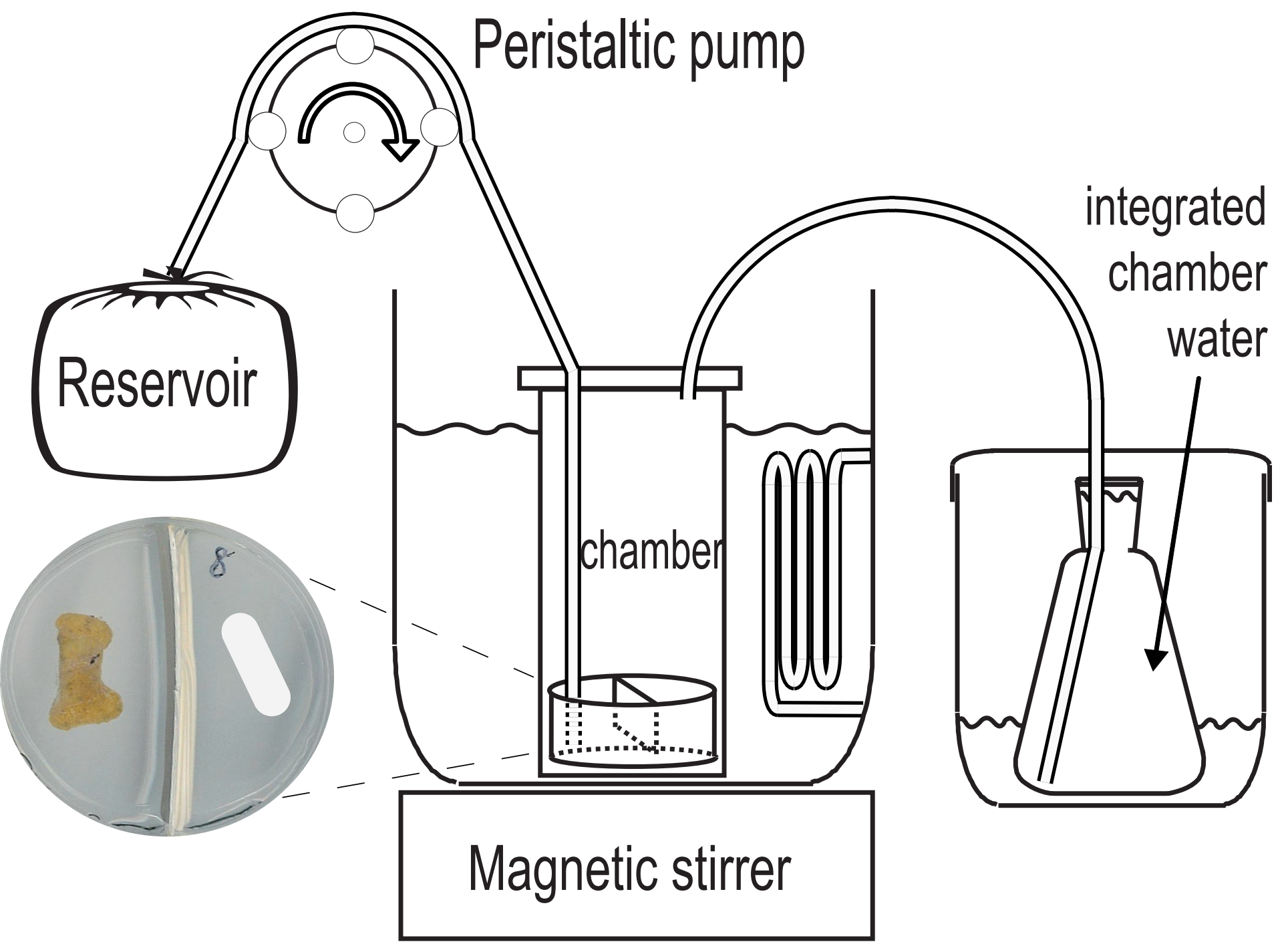

Figure 2 


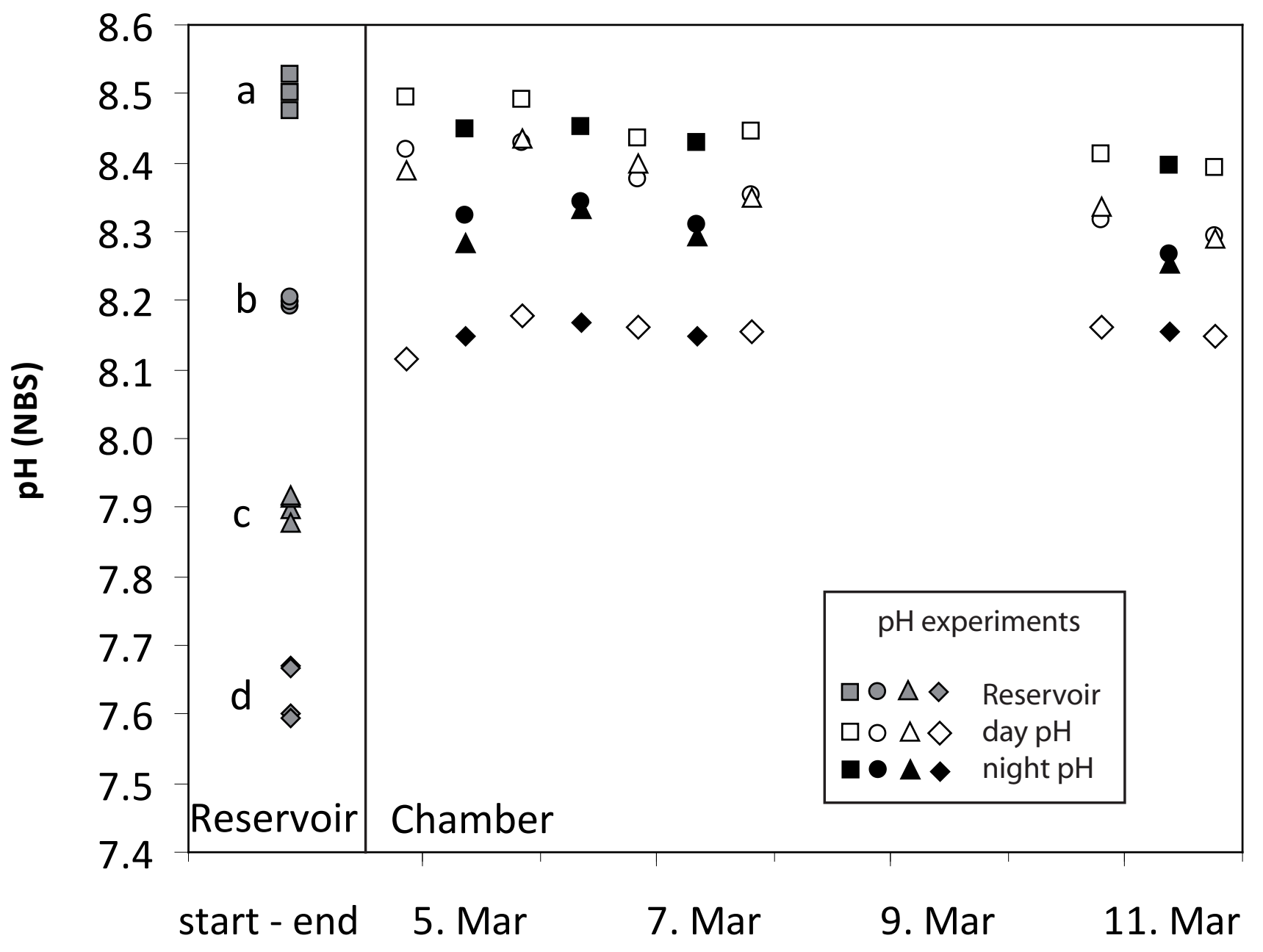

Figure 3 

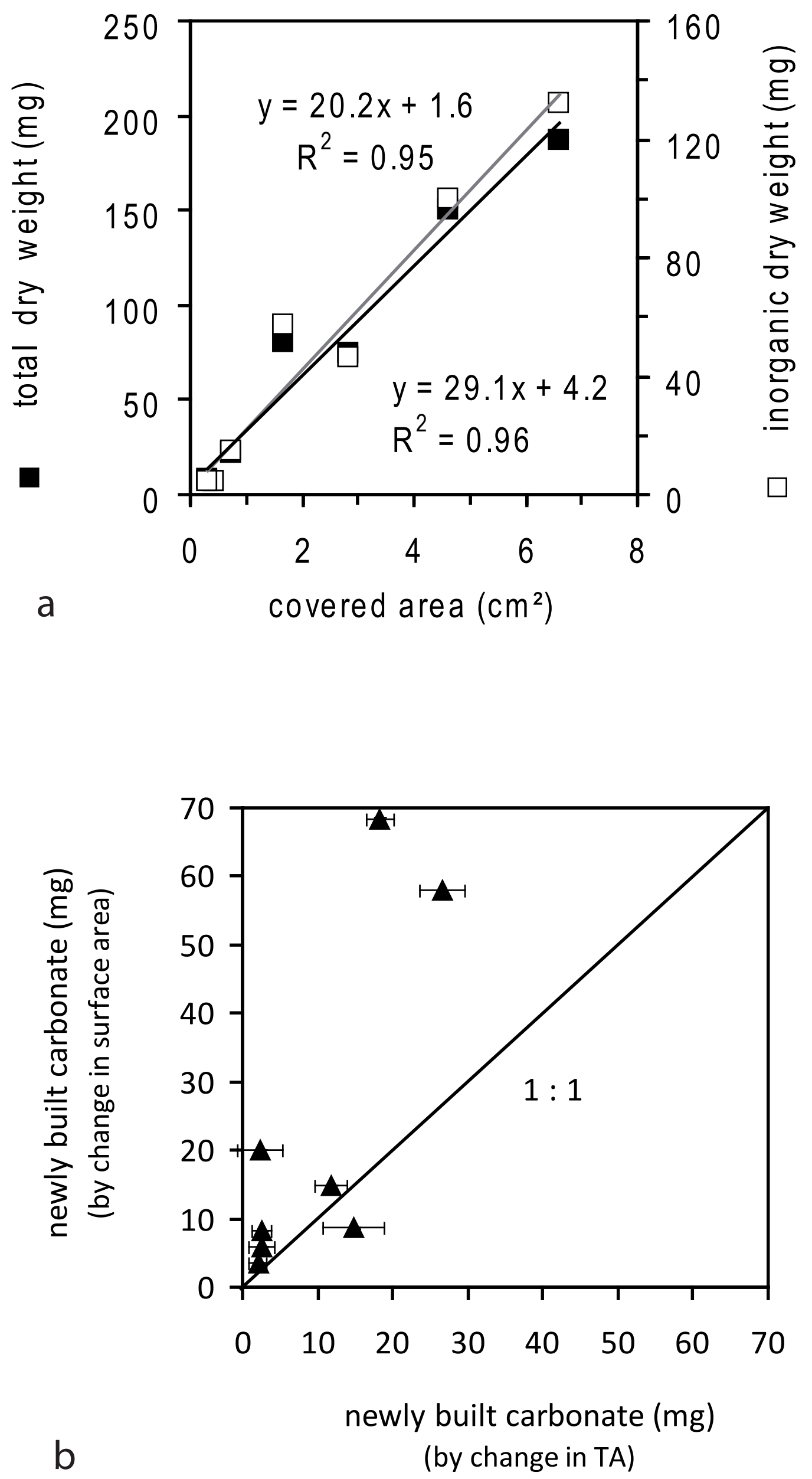

Figure 4 


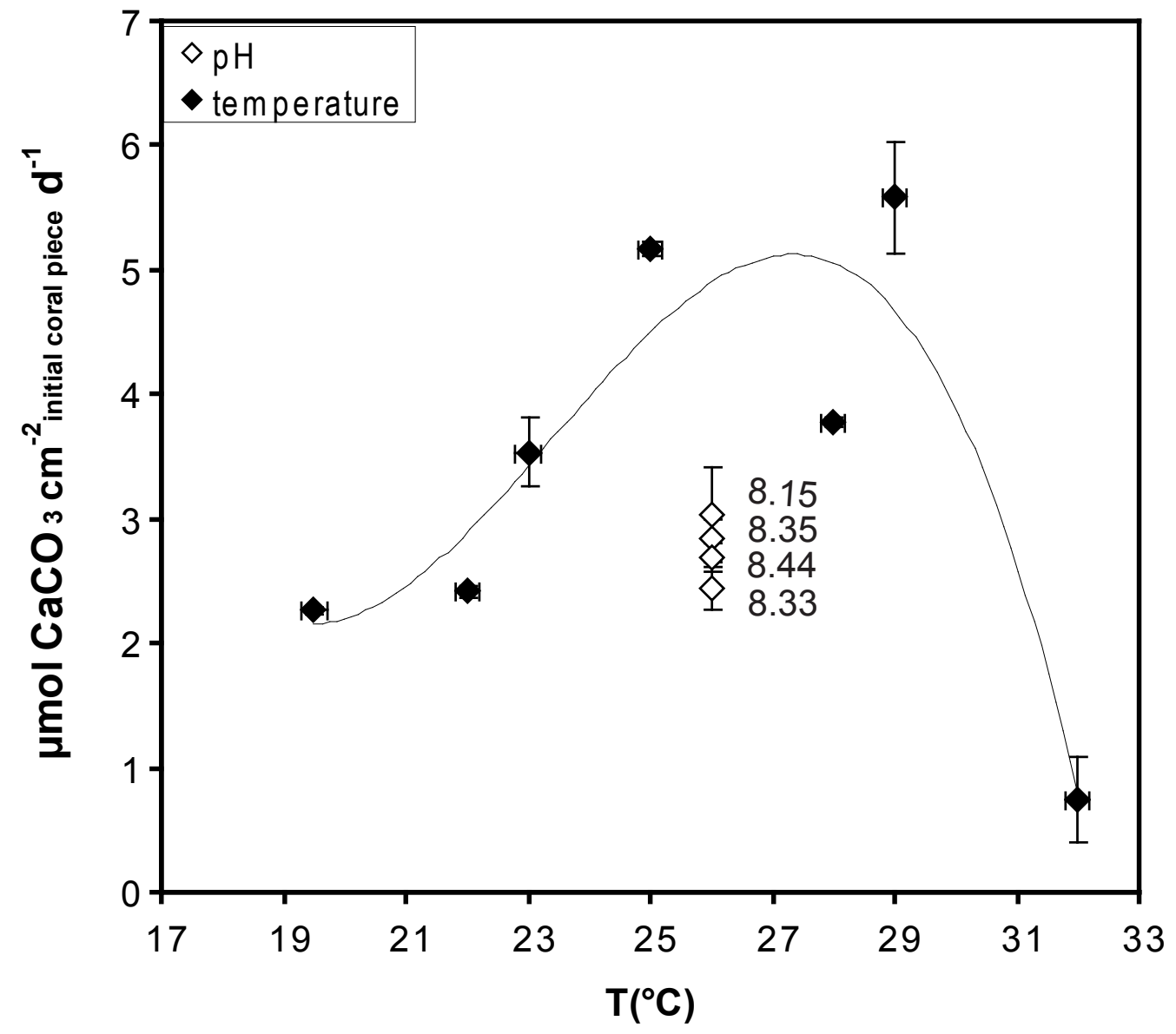

Figure 5 

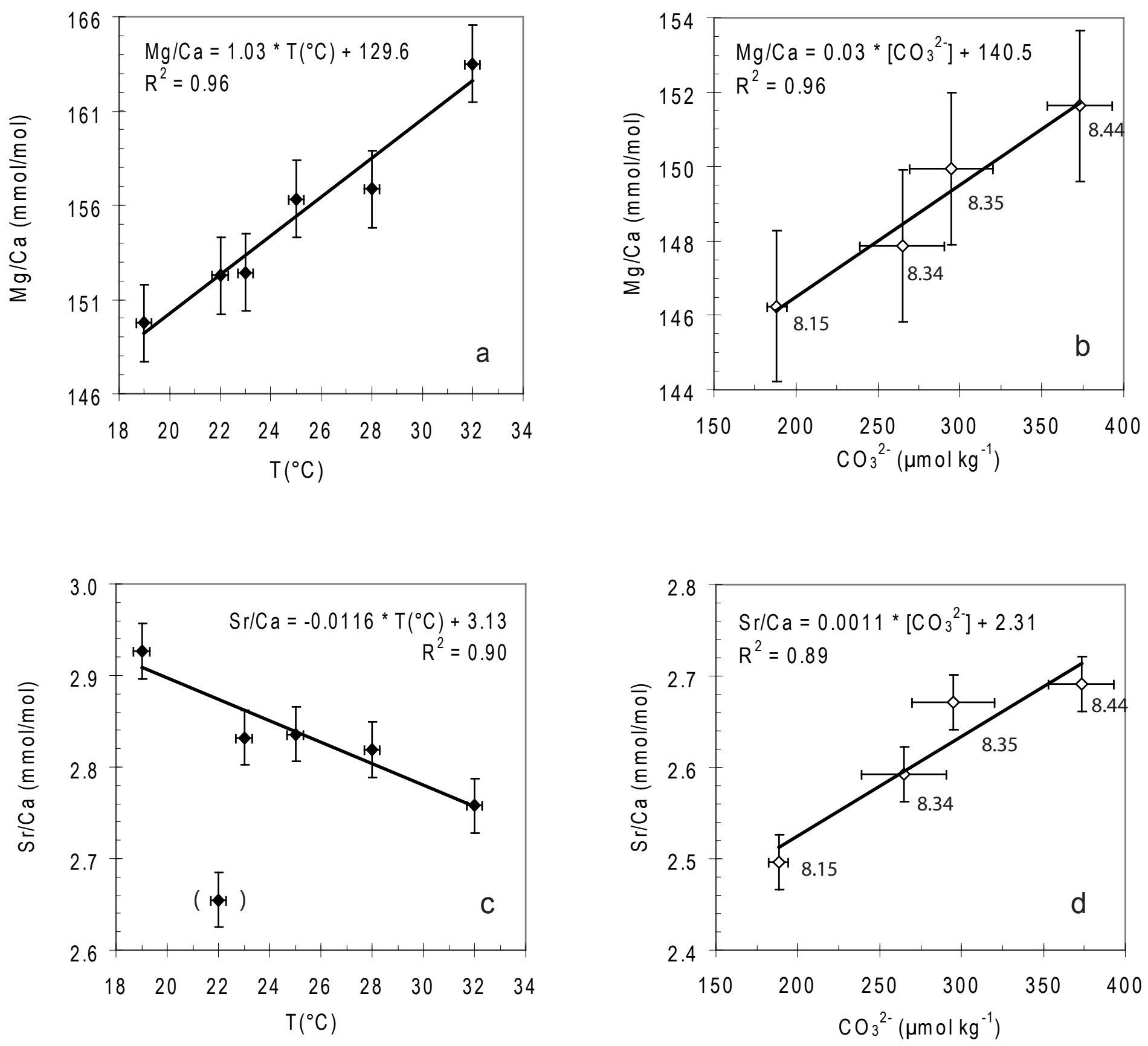

Figure 6 


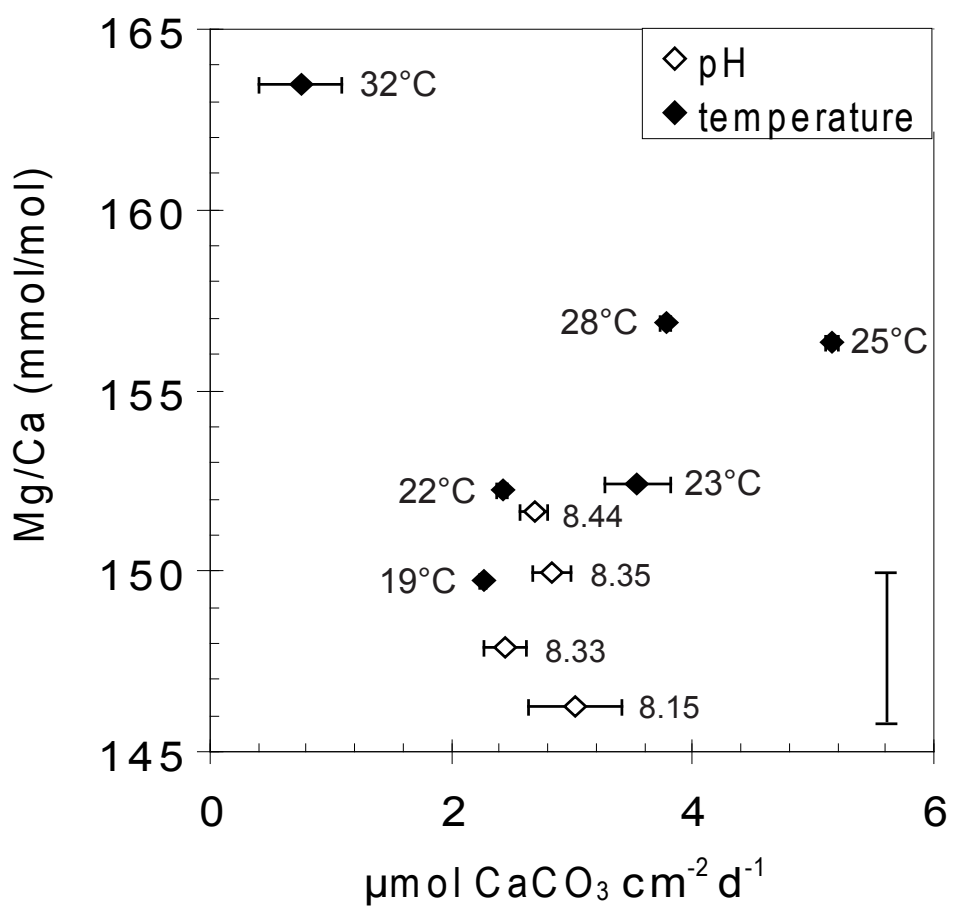

Figure 7 

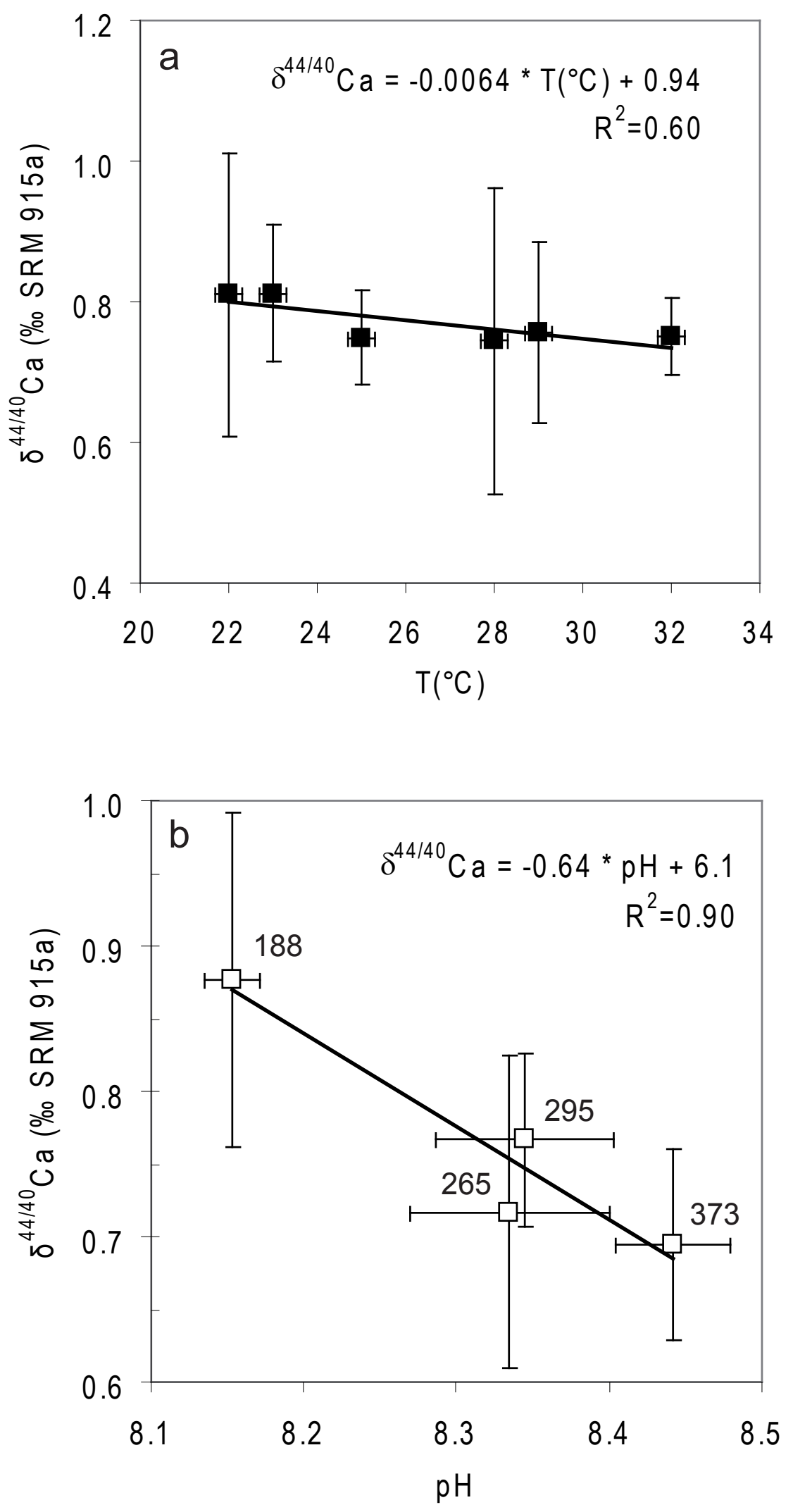

Figure 8 

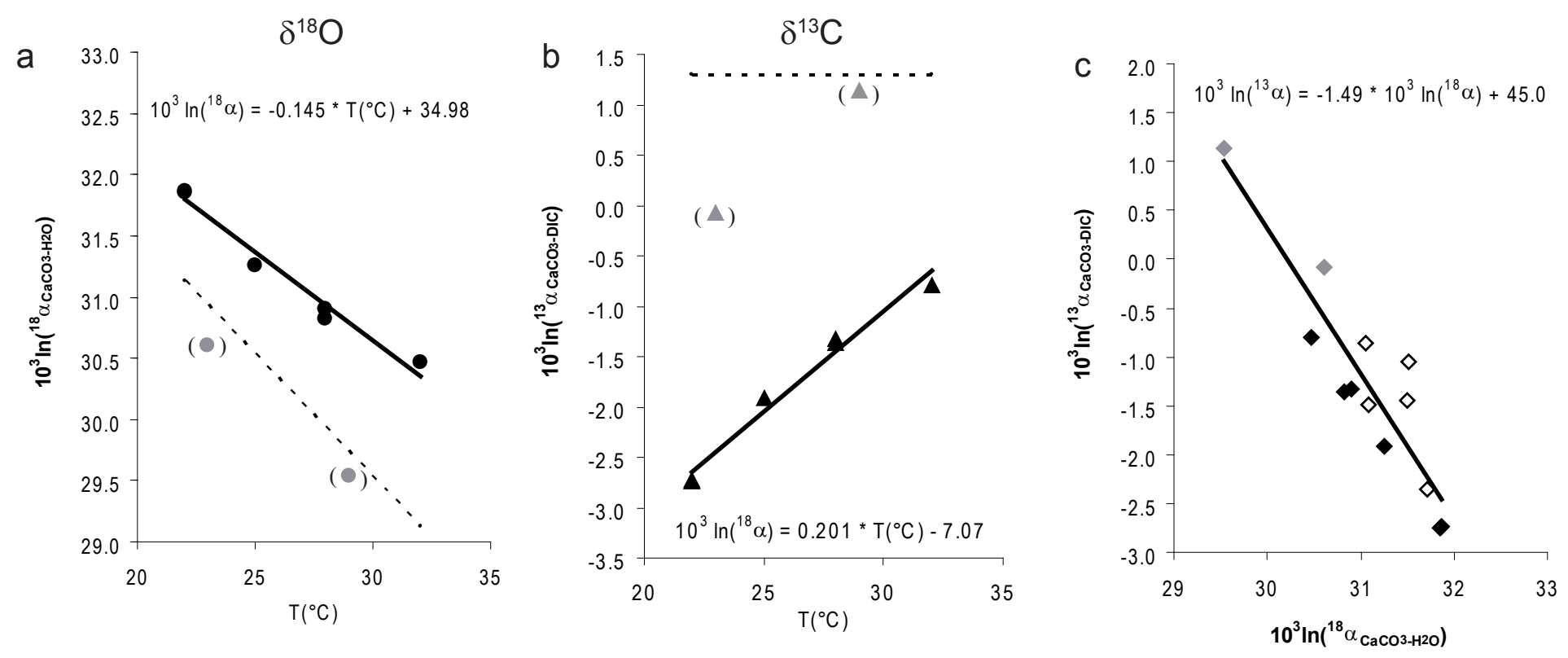

Figure 9 


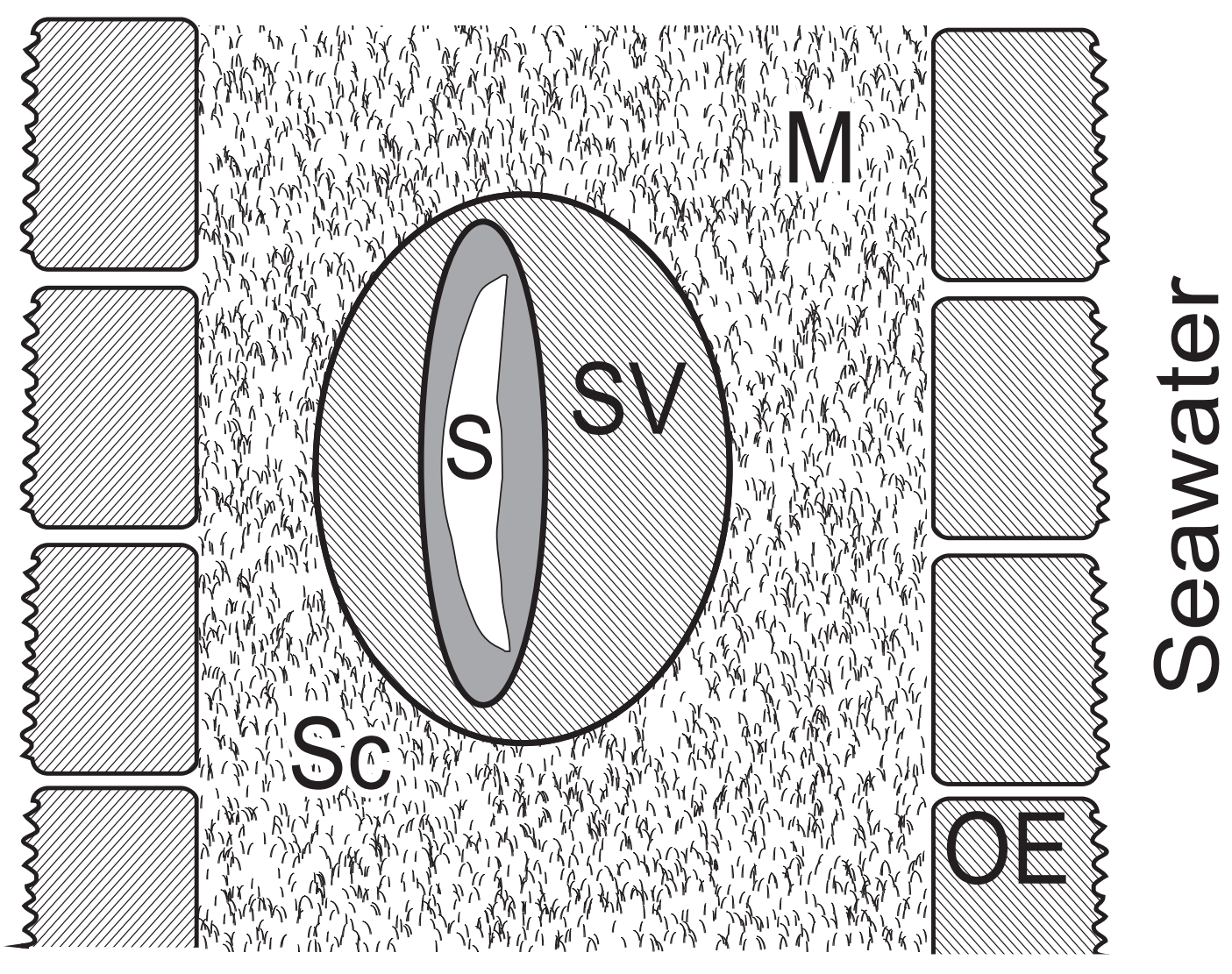

Figure 10 


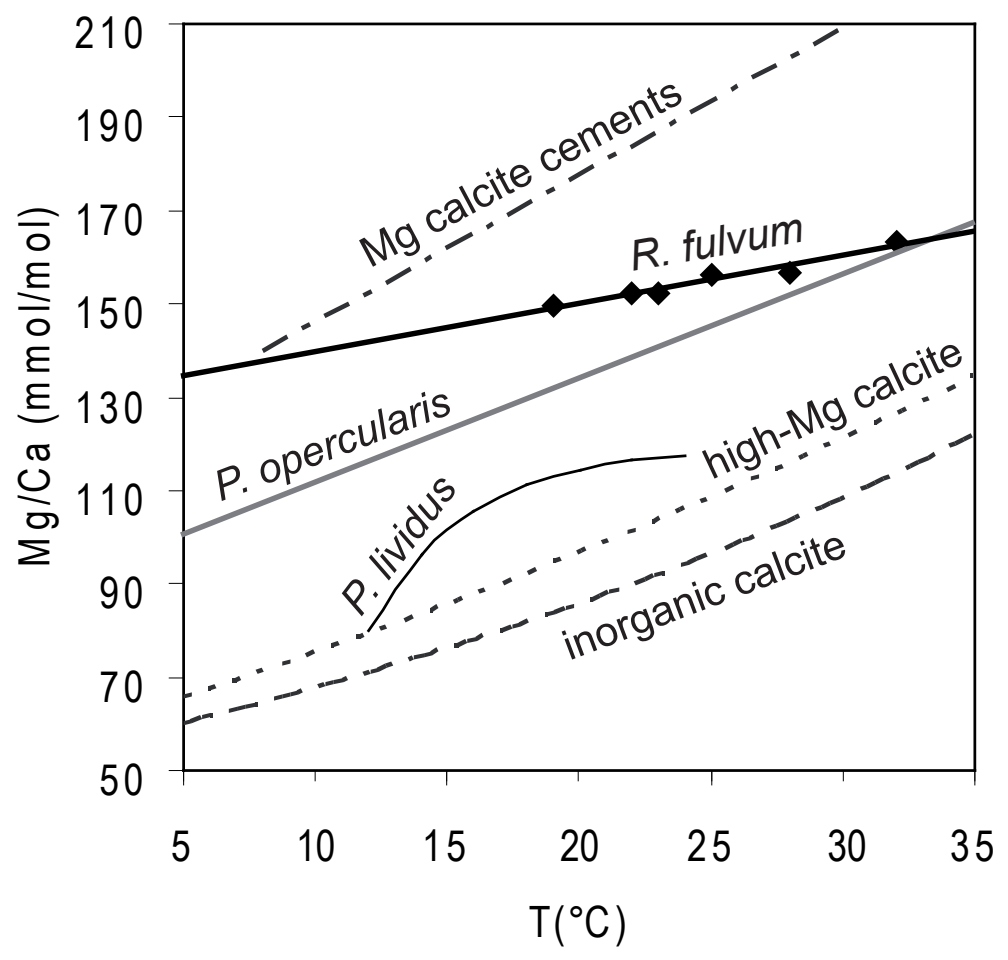

Figure 11 


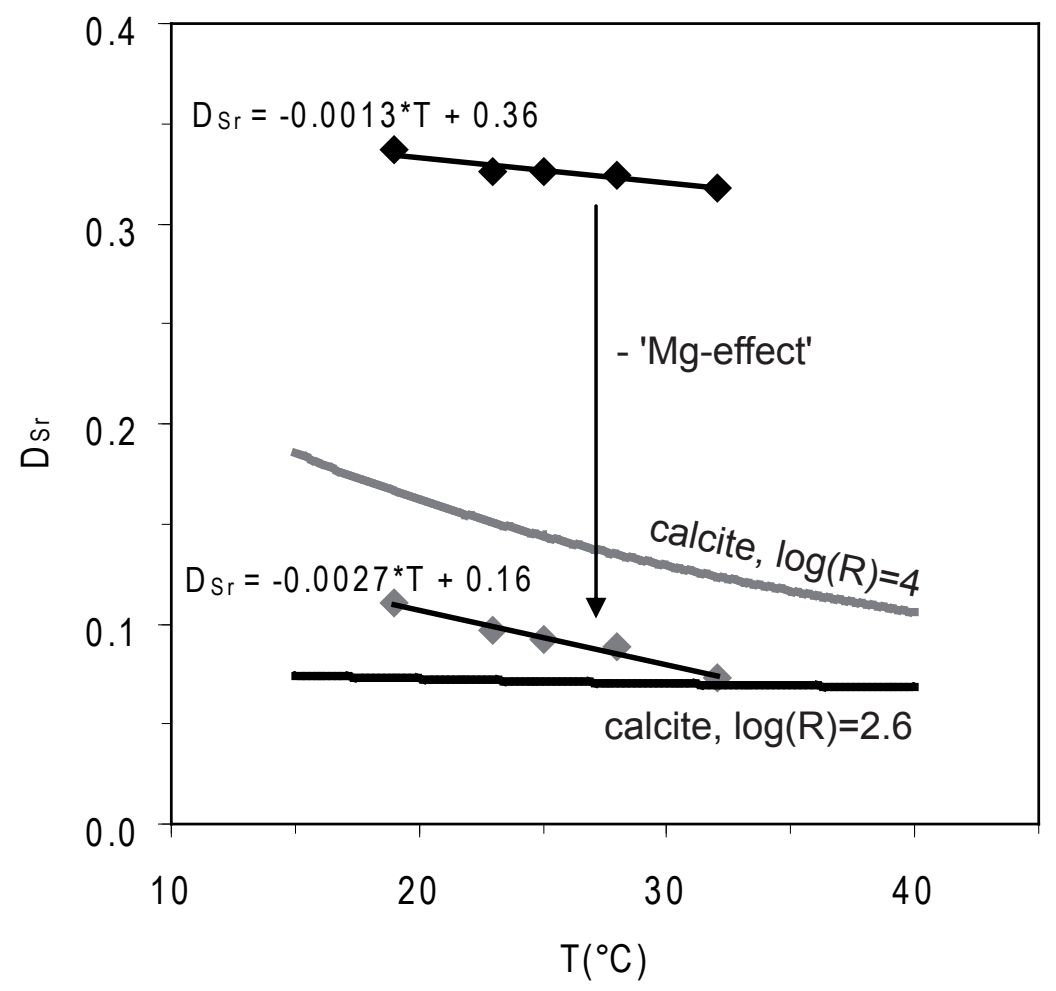

Figure 12 

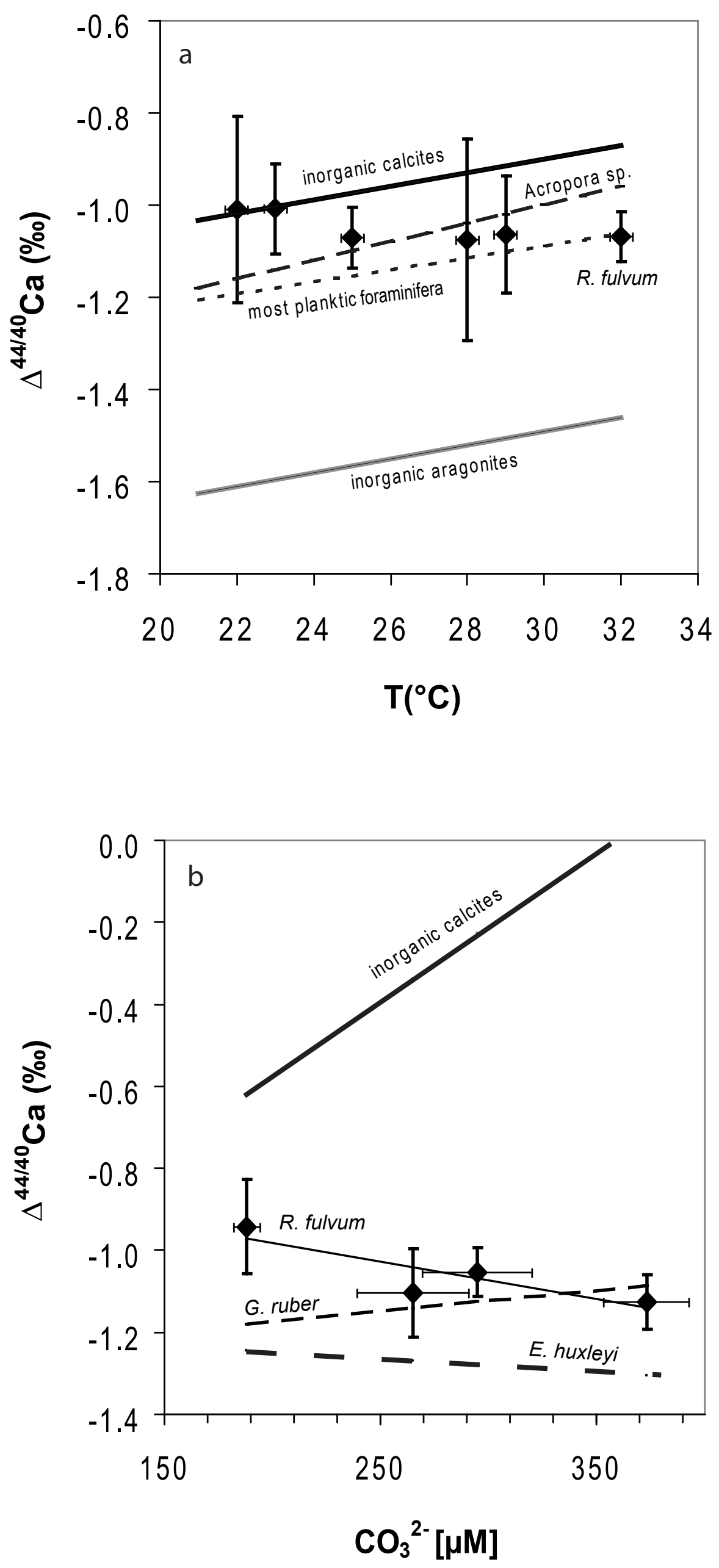

Figure 13 


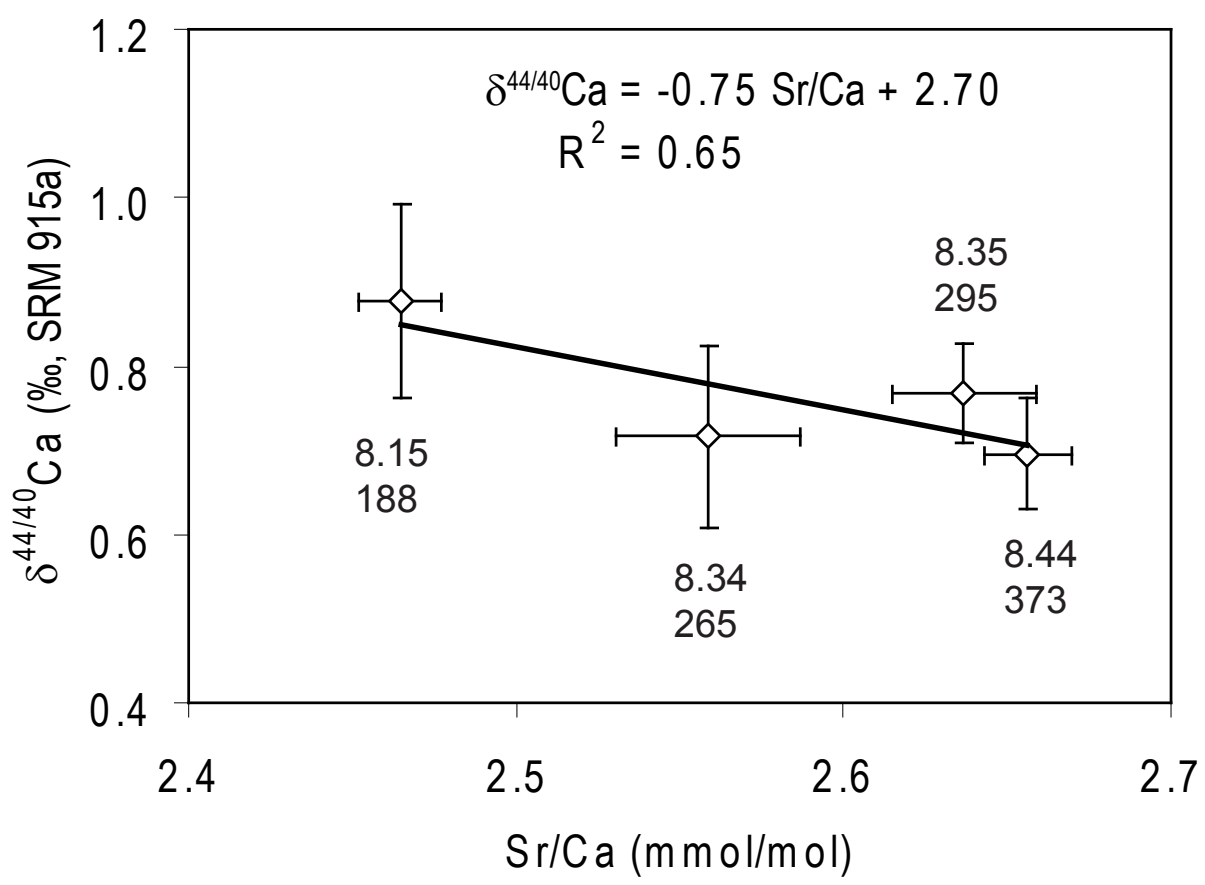

Figure 14 
